\title{
Audits for Accountability: Evidence from Municipal By-Elections in South Africa
}

\author{
May 14, 2021 \\ Daniel Berliner* and Joachim Wehner ${ }^{\dagger}$ \\ London School of Economics and Political Science \\ Conditionally accepted, The Journal of Politics
}

* Associate Professor of Political Science and Public Policy, Department of Government, London School of Economics and Political Science, d.berliner@lse.ac.uk.

$\dagger$ Associate Professor in Public Policy, Department of Government, London School of

Economics and Political Science,j.h.wehner@1se.ac.uk.

\begin{abstract}
:
Theories of retrospective accountability assume that voters punish poor governance and reward improvements, yet empirical evidence remains mixed. We extend this research to a new context, assessing the impact of audits on electoral outcomes in South African municipalities. Our novel identification strategy focuses on by-elections triggered by deaths in office of local councilors and compares those taking place before and after audit results are announced each year. We find that timely audit information affects the vote share of the responsible party, with voters rewarding improvements and punishing poor audits by about 5 percentage points. Additional individual-level survey evidence confirms the underpinning behavioral response more generally. Our study is the first to demonstrate electoral accountability effects of audit information at full scale, involving universal spatial and temporal coverage as well as public and organic dissemination.
\end{abstract}

Keywords: Accountability; audits; corruption; elections; South Africa; transparency

Supplementary material for this article is available in the Appendix in the online edition. Replication files are available in the JOP Data Archive on Dataverse (http://thedata.harvard.edu/dvn/dv/jop). We gratefully acknowledge financial support for this project from the Suntory and Toyota International Centres for Economics and Related Disciplines (STICERD) and the Department of Government at LSE. 
Can institutions of horizontal accountability serve to enable vertical accountability through electoral sanctioning? To retrospectively reward or punish politicians, voters require timely and credible information on their actions in office (e.g., Fiorina 1981, Przeworski et al. 1999). A large literature investigates voter responses to information about corruption or the performance of incumbents (e.g., Healy and Malhotra 2013, de Vries and Solaz 2017, Dunning et al. 2019a), including from audits by official oversight bodies suggesting financial malfeasance. While some find that audits do allow voters to punish poor governance (Ferraz and Finan 2008, Larreguy et al. 2014, Bobonis et al. 2016), others yield mixed results (Chong et al. 2015, Buntaine et al. 2018; Arias et al. 2019a, 2019b). Boas et al. (2019: 398) even conclude that their findings "cast doubt upon the ability of horizontal accountability institutions to induce vertical accountability through public information campaigns." Yet this scholarly pessimism comes at a time of renewed investment in audit institutions around the world.

Clarifying when and where audit information can support electoral accountability remains essential, for several reasons. First, effective horizontal accountability institutions have been identified as crucial for the consolidation of new democracies (O'Donnell 1998), including potentially enabling electoral sanctions (Boas et al. 2019). Second, increased funding is being channeled towards supporting "supreme audit institutions" such as auditors-general or audit courts. In 2017, one initiative recorded USD 68.4 million in annual support for capacity building of these bodies in developing countries, with 583 projects in 198 locations. ${ }^{1}$ One stated aim of this work is to increase their impact on accountability. Third, research highlights the importance

\footnotetext{
${ }^{1}$ Since 2009, 23 bilateral and multilateral donors, including the World Bank and the International Monetary Fund, have coordinated this work in cooperation with the International Organization of Supreme Audit Institutions (INTOSAI). See https://intosaidonor.org/sai-capacity-database/ [accessed October 15, 2019].
} 
of public dissemination, political salience, and opportunities for coordination as conditions for information to influence electoral behavior (e.g., Chang et al. 2010, Adida et al. 2019). While audit information can enable these conditions, this potential varies importantly by context.

We offer new evidence, from a new context, by studying the effects of municipal audits in South Africa. As every municipality is audited every year, and local elections are held all at once every five years, we adopt a novel strategy for comparison. We focus on by-elections triggered by deaths in office, comparing those where citizens do, and do not, have access to timely audit information. Analyzing the period 2008 to 2015, we assess the impact on governing party vote shares of the Auditor-General's annual release of municipal audit results. This report receives a high level of media attention and its findings are used by political actors. Comparing by-elections held in the periods after each report's release date, with those held during the rest of each year, allows us to isolate the effect of audit information from underlying governance conditions themselves. Our identification strategy thus relies on a natural experiment created by the confluence of by-elections and audit releases. Our qualitative and quantitative assessments rule out manipulation of their relative timing.

We find that voters punish poor audits and reward improvements, with effects on the vote share of the responsible mayor's party equivalent to roughly 5 percentage points. We also detect very similar patterns in a separate analysis, using individual-level evidence from a nationwide survey in the field before and after the release of the 2016-17 municipal audit report. Comparing the periods before and after the release date, evaluations of mayoral performance improved in municipalities where the new information demonstrated positive change and vice versa. Further, we find that the post-release period sees increases in information salience, but not issue salience. 
Studying these questions in the case of South Africa is particularly important for several reasons. First, our evidence is from a new context where information is published by a credible (and politically independent) official oversight body, based on audits conducted annually across all municipalities rather than only a selection, and transmitted through regular media and organizational channels that ensure nationwide attention. To our knowledge, no prior study published to date has documented electoral impacts of audit information at similarly full scale in both coverage and transmission. Second, we analyze two separate but closely aligned datasets, complementing evidence on election outcomes with micro-level survey data to verify underpinning behavioral assumptions. Third, our approach avoids potential concerns about researchers or external actors manipulating information in the context of elections (CroninFurman and Lake 2018, Johnson 2018).

Finally, the South African context offers a "hard case" to identify accountability effects of information, given the importance of both strong parties and racial identities to voting patterns (Ferree 2011), and limited voter knowledge of individual local politicians (Mattes 2008). Most research on the electoral effects of audits has examined directly-elected mayors or other candidate-centered elections. In our case, few voters know the identity of candidates as opposed to their party affiliation. ${ }^{2}$ Moreover, the information treatment pertains to a political party governing a municipality rather than an individual seeking reelection - after all, the incumbent is deceased. South African mayors are not directly elected but chosen from among local councils based on party majorities. By examining the electoral effects of information in a party-centered system, we help to clarify scope conditions (Grossman and Michelitch 2018: 295).

\footnotetext{
${ }^{2}$ Only 14 percent of South Africans could name their local councilor in 2006, the third-lowest figure among 17 African countries (Mattes 2008: 120).
} 
We proceed as follows: The next sections discuss our contribution in the context of prior work and provide background on our empirical setting. We then discuss our research design, data and specification, and results, before assessing the wider implications of our findings.

\section{Why and When Audit Information Works for Accountability}

Theories of retrospective accountability (e.g., Fiorina 1981, Przeworski et al. 1999) suggest that credible and salient information about performance allows voters to reward incumbents for better outcomes and punish them for worse ones. This expectation has been tested with different types of information, including on the job performance of individual politicians (e.g., Humphreys and Weinstein 2012, Grossman and Mitchelitch 2018, Adida et al. 2019), quality of public services (e.g., Boyne et al. 2009, Lieberman et al. 2014, Gottlieb 2016), or, as in this study, corruption and financial malfeasance. Many donors, policymakers, and civil society organizations advocate information-based interventions to improve governance (Kosack and Fung 2014).

We situate our study within one specific domain of research on the electoral effects of information about performance in office: where information originates with official government audit bodies and concerns financial malfeasance; and where studies leverage experimental, quasi- or natural-experimental research designs. ${ }^{3}$ We summarize selected features of existing

\footnotetext{
${ }^{3}$ Dunning (2012: 18-20) distinguishes quasi-experiments with nonrandom treatment assignment from natural experiments with "as-if" randomly-assigned treatments. Other research assesses voter responses to malfeasance using survey experiments (e.g., Winters and Weitz-Shapiro 2013), or observationally based on scandals (e.g., Eggers 2014). However, such research designs each face different limitations. It may be difficult for survey experiments to link to real-world voting behavior; or for observational studies to address concerns over selection-into-treatment, discern the effects of information from scandal itself, or consider positive as well as negative information.
} 
research in this domain in Table A1 in the Online Appendix, including studies in Brazil (Ferraz and Finan 2008, Boas et al. 2019), Mexico (Larreguy et al. 2014; Chong et al. 2015; Arias et al. 2019a, 2019b), Puerto Rico (Bobonis et al. 2016), and Uganda (Buntaine et al. 2018).

Even holding constant the type and source of information - financial audits by official bodies - within this subset of research, however, studies vary along several dimensions. Below, we highlight several of these and suggest that audit institutions can indeed play an important role in enabling electoral accountability, not only due to their potential credibility as sources, but also their potential to introduce information at full scale. By scale we mean both the scale of information - the spatial, temporal, and substantive coverage of information produced about government performance - and scale of transmission - the extent to which the dissemination of this information is both public and organic. These features highlight the novel context of our study, offering the first-ever evidence (to our knowledge) on the electoral impacts of audits at full scale on both dimensions, with a research design that enables identification of causal effects even in the absence of randomized audits ${ }^{4}$ or researcher-manipulated treatments.

\section{Credibility}

Weitz-Shapiro and Winters (2016) show that voters discern between more and less credible sources, and that a country's supreme audit institution can be a trusted source of impartial and reliable information. Several studies thus focus on information that originates with such a source. For instance, in the Metaketa I study, three of six fully-implemented field experiments employed information from a national or subnational audit body (Dunning et al. 2019a).

\footnotetext{
${ }^{4}$ Several studies have leveraged Brazil's randomized municipal audit program for inferential purposes (e.g., Ferraz and Finan 2008, 2011; Brollo 2010; Avis et al. 2018).
} 
Arguably as important is the credibility of the transmitter of this information. Some studies highlight the crucial role of traditional media, especially local radio stations (Ferraz and Finan 2008, Larreguy et al. 2014). Others evaluate information interventions delivered by research organizations (Chong et al. 2015), paid enumerators (Boas et al. 2019), or nongovernmental organizations (Arias et al. 2019a, 2019b; Buntaine et al. 2018). The credibility of these actors can differ substantially across different contexts. For instance, Botero et al. (2015) find that radio stations and newspapers are among the most trusted institutions in Colombia, while non-governmental organizations and political parties are the least trusted. This also points towards an important distinction we discuss further below: some studies involving audit findings examine the effects of these audits per se, as transmitted in their natural environment, while others evaluate campaigns by other actors that reuse this information.

\section{Scale of Information}

One key difference across studies is the scale of audits themselves, in terms of spatial, temporal, and substantive coverage. Audits at full scale are annual and universal in their coverage of the relevant entities and funds audited. Many existing studies, however, focus on contexts where only a limited selection of municipalities are audited each year (e.g., Ferraz and Finan 2008; Larreguy et al. 2014; Arias et al. 2019a, 2019b), where resource constraints mean audits are less frequent (Bobonis et al. 2016: 2376), or where audits cover intergovernmental transfers only. ${ }^{5}$ For instance, the Brazilian audit program of federal transfers evaluated by Ferraz and Finan (2008: 707) excluded the largest 8 percent of municipalities and started with a sample of 26

\footnotetext{
${ }^{5}$ In addition, delays dilute the relevance of audits. In the study by Boas et al. (2019: 390) in Pernambuco, Brazil, audits only inform voters about performance in a new mayor's first year by the end of a four-year term.
} 
municipalities and then expanded to 50 and 60 in monthly lotteries - implying an annualized audit probability of up to 14 percent for about 5000 authorities covered during this period.

Why might audit scale matter? Information that is nationwide in scope is likely to receive more media attention and thus be more salient to voters (McCombs and Shaw 1972). Universality of coverage enables systematic comparisons across entities, and repetition over time facilitates comparisons with past performance. A more established audit program also means that the resulting information has had time to become a regularized, expected part of the political context, and to establish a track record of credibility - all features that may be more difficult for a new form of political information introduced for the first time. Regular and timely intervals aid the relevance of information for electoral decisions. Hence, studies of partial-scale information may underestimate the effects of full-scale information.

But importantly, the reverse may also be true. Others have noted how results from smallscale development interventions may not hold when scaled up (Banerjee and Duflo 2009:167169, Deaton and Cartwright 2018), for reasons including negative spillovers, heterogeneous effects, or general equilibrium adjustments. In the case of audit information, full spatial and temporal scale could offer politicians greater opportunities to adjust their behavior or induce political backlashes. The "novelty factor" of audits may wear off once they are ubiquitous and familiar. It is thus essential to confirm whether the effects of partial-scale audits identified in existing studies can, in fact, hold at full scale.

\section{Scale of Transmission}

How do voters receive information about politician malfeasance? In ordinary electoral situations, information reaches voters through both public dissemination from media sources and private 
dissemination via communications from political organizations or through social networks. This diffusion of information is organic, arriving endogenously via familiar channels in which the political context is clear, rather than induced (Mansuri and Rao 2012) as in the case of externally-manipulated information interventions delivered by private companies, researchers, or civil society organizations. Information that reaches citizens through channels that are regular and familiar may be more likely to receive attention, and to be understood and trusted. Media attention in particular means that information occupies scarce space on the public agenda (Chang et al. 2010), further increasing its salience. This can also help induce common knowledge (Adida et al. 2019) and enable voter coordination (Arias et al. 2019a) through the recognition that citizens in other locales have access to similar information.

Quasi- or natural-experimental studies of audits (Ferraz and Finan 2008, Larreguy et al. 2014, Bobonis et al. 2016) are able to capture public dissemination through organic channels. However, the difficulty of experimentally manipulating such transmission, and the popularity of civil society-led information campaigns, have led many studies to instead evaluate information interventions in which the availability of information is induced. Such studies involve partnering with civil society or research organizations to disseminate information privately via flyers (Chong et al. 2015, Boas et al. 2019), leaflets (Arias et al. 2019a, 2019b), or SMS messages (Buntaine et al. 2018). Arias et al (2019b) sought to activate a public transmission channel by accompanying the distribution of leaflets with loudspeaker announcements. Yet in these voter campaigns, such induced transmission of audit results is often distinct from established channels that individuals trust to convey credible and politically-relevant information.

Recent work also aligns with this argument. A meta-analysis of six coordinated field experiments about electoral accountability found "no evidence of overall impact of standard, 
nonpartisan voter information campaigns targeted to individual voters" but noted that "we cannot rule out the possibility that interventions at a much greater scale could have positive effects" (Dunning et al. 2019b: 7-8). Moreover, some pre-registered tests did identify effects of information specifically when provided in a public setting (Dunning et al. 2019a: 369-372).

\section{Our Study}

To our knowledge, this study is the first to assess the electoral impacts of full-scale audit information that is annual, well-established, and universal in coverage, and that is fully public and organic in transmission. Indeed, it is precisely the partial scale of audits in Brazil, Mexico, and Puerto Rico that has been crucial to past research designs enabling the study of information transmitted via public channels. A context like South Africa, in which every municipality is audited every year, has normally presented challenges for identifying a comparison group.

We thus offer evidence from a novel and important context, in terms of the credibility and scales of information and dissemination of audits. Given the macro-level nature of these contextual features, we cannot explicitly vary them. Rather, our study fills a major gap in existing research and highlights the importance of these factors in light of the range of findings made by past work. We demonstrate that previous quasi- or natural-experimental findings with partial-scale audits can, in fact, scale up.

\section{The South African Context}

We examine the electoral effects of South African local government audits. Following the country's transition to democracy, the 1996 Constitution charged municipalities with providing essential basic services (Kroth et al. 2016). Despite reforms to improve municipal financial 
management and service delivery, progress remained disappointing (Berliner 2017). In 2009, President Jacob Zuma of the African National Congress (ANC) launched an ambitious turnaround initiative, "Operation Clean Audit 2014."” It promised "clean audits" - certifying flawless financial and other reporting and full compliance with legislation - for all provincial and local governments within five years (Appendix Table A2 provides full definitions of audit outcomes). The target was missed by a wide margin (Table A3).

South Africa's 1996 Constitution establishes the Auditor-General as one of six institutions meant to "strengthen constitutional democracy" (section 181). As the country's supreme audit institution, the Auditor-General audits and reports on the accounts, financial statements, and financial management of national, provincial, and municipal governments (section 188). All reports must be made public. The audit process is set out in the Municipal Finance Management Act of 2003 (sections 126 and 127). Within two months after the end of the financial year on June 30, the accounting officer of a municipality has to submit financial statements to the Auditor-General. Upon receipt, the Auditor-General has three months to complete an audit and to submit the results to the municipality. Hence, each municipality's audit result should be finalized by the end of November. No later than seven months after the end of a financial year, the mayor of a municipality must table an annual report including the audit outcome in the municipal council. In practice, however, local releases rarely align with this January deadline, and audit results often receive little attention until months later.

Since 2009, the Auditor-General has publicly released a summary report on audit results for all municipalities pertaining to the financial year ending roughly one year prior, published on a date around the middle of each year. It is these nationwide reports that receive predominant

\footnotetext{
${ }^{6}$ This followed an earlier initiative, "Project Consolidate," launched by President Thabo Mbeki in 2004.
} 
attention, and are widely reported in national and local media, including newspapers, ${ }^{7}$ radio, television, ${ }^{8}$ and the internet. ${ }^{9}$ The Auditor-General holds a series of events to publicize the results and to maximize their local salience. ${ }^{10}$ Figure 1 plots newspaper articles mentioning terms indicative of municipal audits (see also Appendix Figure A1). The seven highest article counts all immediately follow release dates, yet such mid-year spikes are absent prior to the 2009 introduction of comprehensive nationwide summary reports.

In 2018, the South African Citizen Survey asked a representative sample of South Africans about municipal audits and the Auditor-General. Weighted responses for March and April 2018 show 24 percent of respondents claimed they had heard, seen, or read about their municipality's audit result, while 25 percent claimed to have heard, seen, or read about reports of unauthorized, irregular, or fruitless and wasteful spending by their municipality (with 35 percent having heard of either). Moreover, excluding "don't knows," 56 percent had "a lot of" or "some" trust in the Auditor-General, against 42 percent for their mayor. Fully 59 percent of respondents said that information about corruption and financial mismanagement in their municipality was "very" important, and another 25 percent "somewhat" important, in deciding which political party to vote for in a municipal election or by-election. Municipalities and political parties also use audit results in their own campaigns. ${ }^{11}$

\footnotetext{
${ }^{7}$ E.g., “All eyes on auditor-general's local government audit”, Sunday Independent, August 11, 2013.

${ }^{8}$ E.g., “Auditor-general's report shows irregular expenditure in municipalities”, SABC News, June 1, 2016.

9 E.g., Eyewitness News, a news publisher, established a "Municipal Audits" website (Appendix Figure A2).

${ }^{10}$ E.g., “A-G's roadshow paints a bleak picture”, Diamond Fields Advertiser, March 30, 2012.

${ }^{11}$ Appendix Figures A3 and A4 show adverts by an ANC-run municipality boasting a clean audit ahead of local elections, and the opposition Democratic Alliance (DA) using audits as evidence of good governance credentials.
} 
Figure 1: Media attention to municipal audits spikes after the release of the Auditor-General's report

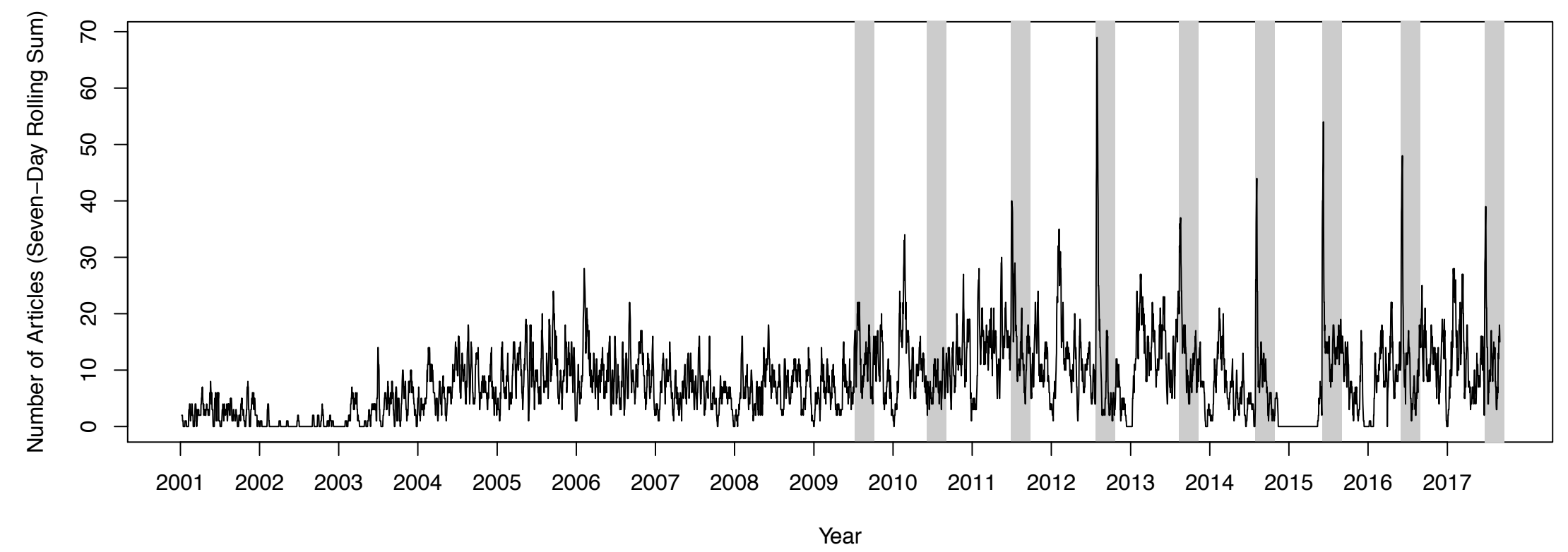

Note: The grey shaded areas indicate 90-day periods following the release of an Auditor-General's summary report on municipal audits. The number of articles was calculated as the seven-day rolling sum of newspaper articles extracted from Sabinet's SA Media database over the period January 29-31, 2018, using the following search query: (municipal OR municipality OR "local government") AND (audit OR "auditor general" OR "irregular expenditure" OR "unauthorised expenditure" OR "fruitless and wasteful expenditure"). At the time of data extraction, the database covered 38 mainstream South African media publications with national or regional distribution. A change in Sabinet's collection procedure resulted in a gap in coverage from late 2014 to early 2015 , visible as the flat line over that period. 
The first elections to restructured local councils took place in late 2000 , followed by regular elections in 2006, 2011, and 2016. Municipalities are headed by mayors chosen by a majority on the local council, in some cases (roughly 15 percent after the 2011 elections) requiring a coalition where no party holds a majority of seats. Municipalities use a mixed system whereby half of the seats on a council are elected under plurality rule in single-member wards, and the other half under proportional representation with closed party lists. Our focus is on ward seats, for which by-elections are held to fill vacancies. According to the Municipal Structures Act (section 25), these have to occur within 90 days of a vacancy.

\section{Research Design}

South Africa's Auditor-General audits every municipality in each year. This creates a challenge for evaluating the electoral effects of this information, as regular elections are also held for all municipalities at the same time, every five years. If we were to compare the performance of the mayor's party in local elections between municipalities with good and poor audit results, we would have no control group where citizens received no information. Our solution is to focus on by-elections (Appendix Table A4). From 2007 to 2015, there were a total of 949 by-elections in 209 municipalities out of 234 in total as of 2011. These by-elections took place irregularly throughout the year and the IEC grouped several on the same day, generally every few weeks. The average by-election date saw elections for new councilors in about ten wards around the country, and roughly ten such dates were held each year on average in this period.

We thus compare by-elections held shortly after the annual release of the AuditorGeneral's nationwide report on municipal audit results - when information closely related to corruption and financial mismanagement is available, prominent, and timely - with by-elections 
held during the rest of the year. The number of by-elections is smaller when we examine a narrower window just before and after the release dates, which we do in a robustness check. As shown in Appendix Figure A5, our "treatment" of interest is the presence of timely and salient audit information at the time of a by-election. Our primary treatment window is the 90 days immediately following each audit release. We vary this period to validate that recency matters.

To support a causal interpretation of our results, we analyze by-elections triggered by the death of an incumbent councilor for a particular ward (Jones and Olken 2005). Other triggers involve greater potential for strategic timing or reflect political conditions. ${ }^{12}$ Our identifying assumption is thus that our information treatments can be considered "as-if" random, exogenous to by-election outcomes or the underlying differences in the location or context of by-elections. In other words, the timing of the by-elections in our sample relative to the national release of audit information has to be random. The remainder of this section probes this assumption. Following Dunning (2012), we focus on three factors to evaluate the plausibility of our as-if random natural-experimental treatment: information, incentives, and capacities.

In this case, municipal politicians do indeed know their audit results before the national release date. They also plausibly have incentives to manipulate timing: The governing party of a municipality would presumably prefer to face by-elections ahead of the release date if the results will reflect poorly on their performance, and afterwards if results will reflect positively. In terms of capacities, some by-election triggers such as resignations and expulsions could indeed be strategically timed such that by-elections fell either before or after the release date of audits.

\footnotetext{
${ }^{12}$ Ward by-elections are triggered when a councilor resigns, is no longer qualified (as set out in section 158 of the 1996 Constitution), is removed from office due to a violation of the Code of Conduct for Councilors, changes partisan affiliation, or dies.
} 
Deaths in office, however, are presumably randomly timed. Moreover, the Municipal Structures Act (section 25) requires the municipal manager, not political officials or parties, to liaise with the IEC so that a by-election is held within 90 days of the date on which a vacancy occurred. ${ }^{13}$ While the IEC theoretically could attempt to manipulate a timetable (on which several by-elections are held around the country), this would require overcoming a coordination problem between potentially diverging local needs of the ruling ANC in different municipalities. In one municipality the local ANC might prefer the by-election be held before audit information is available, in another afterwards, depending on the nature of the information and which party is responsible. By-elections on any given date are likely to fall into different provinces, so collusion would also require coordination across provincial authorities. Moreover, the 90-day deadline allows very little slack (footnote 13). Taken together, these factors make it arguably impossible for the IEC to act in this way - even if it were unable to resist political pressure.

Another possibility is that the Auditor-General's national release date itself might be strategically manipulated for political gain. Might the nationally-governing ANC pressure the Auditor-General to delay the release by a few weeks until after a series of competitive byelections had passed? We do not think this is plausible, given the independence of the AuditorGeneral and the same coordination problem across different localities. In practice, the annual release date for the municipal audit report is set by the Auditor-General in an internal planning

\footnotetext{
${ }^{13}$ News of the death of a local politician is difficult to suppress and any attempts by municipal managers to delay notification of the IEC would be highly unusual. If a municipal manager fails to consult the IEC and announce a byelection date within 14 days of the vacancy occurring, the Act requires the provincial government to do so. In practice, electoral officials suggested average timelines of around 80 days to fill a ward vacancy, and slightly longer since a 2016 Constitutional Court ruling requiring improved voter data (email communication).
} 
meeting months before the dates of any relevant by-elections are known. This also means there is no scope for any actor to attempt to strategically manipulate the outcomes of individual audits, which are finalized before future by-elections are triggered.

We can even observe a most-likely case for political pressure to succeed. The 2016 municipal elections, originally scheduled for February, had to be delayed until August due to a Constitutional Court ruling about updates to the voters' roll. These elections, in which every local council would be reelected, were widely seen as important and ultimately delivered the largest electoral blow yet to the ANC's hold on power (Olver 2017). Originally scheduled to take place before the national audit release in June, the court ruling meant that these elections would instead take place shortly afterwards. If ever there were a time for the ANC to pressure the Auditor-General to delay the release, this was it. That the national audit release instead took place as scheduled, attracting substantial news coverage in the context of the upcoming elections, shows the limited potential for such manipulation. ${ }^{14}$

It is equally unlikely that local politicians or the ANC can manipulate media coverage of the Auditor-General's report, for example by delaying the transmission of this information to voters or suppressing specific results. South Africa has a vibrant and diverse media landscape. The Press Freedom Index produced by Reporters Without Borders acknowledges threats to media independence but ranks the country similarly to established democracies such as the United States and the United Kingdom. ${ }^{15}$ Figure 1 confirms immediate media transmission following the release of the Auditor-General's report.

\footnotetext{
${ }^{14}$ As City Press noted on June 5, 2016: “The release on Wednesday of the Auditor-General's report on municipalities could be the worst timing for political parties trying to win in the local government elections."

${ }^{15}$ See https://rsf.org/en/ranking/2016 (accessed December 10, 2018).
} 
To further assess the potential for manipulation in the timing of by-elections, we examined balance on several ward- and municipality-level covariates between by-elections inside and outside of 90-day windows following each regular audit release date (Appendix Table A5). Across all by-elections, some imbalanced covariates suggest potential for strategic timing. For by-elections due to death only, we see fewer imbalances and only two are statistically significant at the 10 percent level - roughly what could be expected by chance. We also conducted sorting tests (Figure A6), using the time to or from the nearest national audit release date as the running variable (and excluding years in which no release took place). These detect evidence of sorting across all by-elections, with more by-elections ahead of the release date ( $\mathrm{p}<0.001)$, but not for by-elections due to deaths only $(\mathrm{p}=0.433)$. These results are consistent with our expectation that deaths in office are randomly timed relative to audit release dates. ${ }^{16}$

\section{Data and Specification}

We combine data on elections and by-elections from South Africa's IEC and on audits from the Auditor-General of South Africa, supplemented with municipal-level information collected from Statistics South Africa and other sources.

Our main outcome of interest is the vote share of the party that governs the municipality, but we also examine voter turnout. Turnout is relatively direct - does audit information spur more or fewer registered voters to turn out to vote in by-elections? Notably, turnout is lower in

\footnotetext{
${ }^{16}$ One final concern may be that murders could be strategically timed. One investigation ("In Search of a Political Murder", Daily Maverick, October 20, 2016) found allegedly political murders linked to a variety of local political, business, and employment disputes, as well as theft or mistaken identity, but not audits. Most took place in KwaZulu-Natal, which we exclude in supplementary results.
} 
by-elections than in regular local elections (across all by-elections, the average ward saw turnout drop from 54.7 percent in the previous regular local election to 38.3 percent in the by-election). Voter turnout is observed for all by-elections, except in the 8.5 percent of by-elections which were uncontested. In these cases, only one party fielded a candidate, and no actual by-election was held. As these situations offer no voter behavior to study, we treat them as missing. ${ }^{17}$

Assessing who citizens vote for in by-elections, however, raises thorny issues of attribution. Unlike in Brazil, mayors in South Africa are indirectly elected. The incumbent party in any given ward is thus not necessarily the party responsible for how a municipality is run (but given ANC dominance, this is the case in the majority of observations). Further, as we examine by-elections to replace deceased councilors, incumbents are not on the ballot. Audit information is thus attributable not to the incumbent party for a particular ward council seat, but rather to the party of the mayor who governed the municipality at the time to which the audit pertains. It is this party that citizens would either punish or reward for weak or strong performance. We thus measure the "relevant" or "responsible" party's vote share in each ward, even if this party is not the incumbent party in that ward. For observations with coalition councils we researched the party affiliation of the individual mayor at the close of the fiscal year to which the audit applied (as no centralized source of data on council coalitions yet exists in South Africa).

Attribution is most straightforward where a municipality was run by a single party that held a majority of council seats throughout the relevant fiscal year to which the audit applies and where this party is still in charge at the time of the by-election. Conversely, barriers to attribution may arise when, during the relevant fiscal year covered by the audit, a municipality was governed by a coalition or had multiple mayors from different parties, or when the mayor's party

\footnotetext{
${ }^{17}$ However, we also check our main findings using a Heckman selection approach in the Appendix (see Table A6).
} 
changed in the interim period since the end of the relevant fiscal year (e.g., Schwindt-Bayer and Tavits 2016). In 23 percent of by-elections triggered by death, one or more of these barriers to attribution were present, and we check whether this affects the results.

Our main independent variables are an indicator for a by-election held in the 90 days following a national audit release date, a measure of audit performance, and the interaction between these. Release dates are when the Auditor-General publishes the report on municipal financial management. Audit outcomes fall into several categories defined in Appendix Table A2. In some cases, later reports update previous findings, particularly where municipalities submit missing information at a later date. We use only the contemporaneous audit outcomes as publicized at the time of each national release date. The Auditor-General uses color-coding in reports, in part to aid interpretation of results and their use by citizens (Fung et al. 2007). Clean audits are identified with green, unqualified with yellow, qualified with purple, adverse with pink, disclaimer with red, and outstanding with grey (Figure A7). This audit terminology features regularly in media coverage, as other audits are released at different times of the year for national and provincial departments. Moreover, the reports use a traffic light system and arrows to categorize movements in performance over the prior year as either improved, unchanged, or regressed (e.g., Figure A8). This approach abstracts from the underlying technical categories by focusing on the trend in performance, which is more intuitively understandable.

Our coding of audit outcomes is based on changes over time. These offer new and salient information that has the potential to enable voters to reward the governing party for improvements, or to punish deteriorations. Using the official hierarchy of audit outcomes described above, we adopt the Auditor-General's trichotomous representation of movements over time, with values of one for an improvement, negative one for a decline, and zero for the 
same audit outcome as in the previous financial year. In our sample, 13 percent of observations involve deteriorations in audit performance, and 26 percent improvements.

Our basic model is as follows:

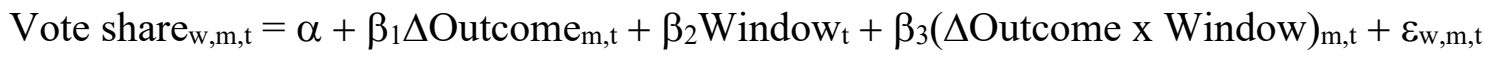
where Vote share is the share of votes in a by-election in ward $w$ of municipality $m$ at time $t$ of the party of the mayor of the municipality who was in power at the end of the fiscal year to which the audit applies. The change in Outcome is our trichotomous measure and captures the latest year-on-year change in the audit outcome for municipality $m$ that should be available at time $t$. We assume municipal audits are finalized as required within five months after the end of a fiscal year, and update the information referenced by Outcome every December 1. Window indicates whether a by-election falls within the post-release window, so that it is treated with timely audit information. We set the post-release window to $x$ days following the nationwide release of the Auditor-General's municipal report, where $x$ is $30,60,90$ or 120, with 90 as our default. We cluster standard errors at the by-election date level, the unit of "as-if-random" treatment assignment, and report various alternatives. We also account for the relevant initial vote share (in the last regular election) and province and year-specific shocks. ${ }^{18} \mathrm{We}$ further dispense with the assumption of linearity and examine deteriorations and improvements in audit performance separately, and report other robustness checks below. The Data Appendix contains definitions and summary statistics (Tables A21 and A22).

\footnotetext{
${ }^{18}$ We adjust the year effects to capture the 12 months to 30 November each year, to reflect the statutory audit cycle. With 268 observations from 144 municipalities in our main regressions, there is no within-variation in the majority of local authorities. We include results with municipality fixed effects from our second dataset.
} 
We are interested in the coefficient on Window, and how it is conditioned by audit performance. Specifically, retrospective accountability leads us to expect the vote share of the responsible party to get a boost from timely news revealing improved audit performance, and for it to drop following news of a deterioration. It is perhaps less obvious what impact we should expect when voters receive timely information that an audit result is the same as in the previous year. The period we examine was characterized by deep and widespread discontent with the dismal state of local governance, including a wave of "service delivery protests" across municipalities that reached "insurrectionary proportions" in some cases (Alexander 2010: 37). The vast majority of municipalities failed to achieve "clean" audits (Appendix Table A3). Where stagnation means the continuation of a poor status quo, it is likely to get punished as well. ${ }^{19}$

\section{Results}

We first evaluate the average effect of a by-election falling into the post-release window, by omitting the interaction term (column 1 of Table 1). The coefficient on Window is negative but not significant at standard levels. This is expected, as the impact of the information treatment is likely to depend on the nature of the news it conveys. Next, we run the basic interactive model specified above (column 2). The coefficient on Window now captures the impact of a by-election being treated with timely information conveying stagnation in audit performance. The coefficient on the interaction term shows a difference of 10 percentage points when an audit outcome improves. The joint effects at the bottom of the table - the sum of the two coefficients - show an

\footnotetext{
${ }^{19}$ E.g. "Service Delivery Protests in South Africa", CCTV News, February 8, 2014, available at https:/www.youtube.com/watch?v=guNv1-bNeOE (accessed September 26, 2018). In this example, community members explain their protest with a lack of progress. Says one: "There is no change at all!"
} 
overall positive (negative) impact of timely news of better (worse) audit performance of about 10 percentage points. This pattern is similar once we account for the initial vote share of the relevant party in that ward in the last regular municipal election (column 3) as well as province and audit year-specific shocks (column 4).

Finally, our baseline model assumes that positive and negative news effects are equal in magnitude. Splitting the audit change variable into two separate indicators (column 5) shows that timely information on deteriorations is punished, and improvements rewarded, by about 5 percentage points, but the effect of deteriorations is not significantly different from that of stagnation. While the number of deteriorations in our dataset may not be enough to distinguish these effects, this result is consistent with a context where new information on stagnation also constitutes "bad news" and voters respond to it just as negatively as to information on worsened performance. Appendix Figure A9 visualizes the effects in columns 4 and 5. Overall, we detect sizable impacts of highly-credible audit information on these as-if-randomly-timed by-elections.

Prior work suggests that recency bias shapes the effect of audits on election outcomes, in that voters give more weight to recent than to older information (Bobonis et al. 2016). We test this by varying the length of the treatment window (Appendix Table A7). When we restrict the window to 30 days, timely dissemination documenting stagnation or a decline in performance incurs penalties of 9 and 21 percentage points of vote share, respectively (column 1). The equivalent figures decline for the 60 and 90-day windows and finally reach zero and 4 percentage points for the 120-day window (columns 2-4). Timely improvements boost electoral performance throughout by about 4 percentage points, although these estimates lack precision. Finally, with a continuous measure of the (logged) number of days since the release of the last 
audit report, improvements are estimated to get less reward, and stagnations and deteriorations less punishment, the further away a by-election is from the release date (column 5).

We report further robustness checks in the Appendix. First, restricting the sample to byelections within 90 days on each side of a release date returns a strong pattern of consistent results, despite the small sample (Table A8). Second, various alternative standard errors make no difference (Table A9). We then drop, in turn, all by-elections that occurred in each of the nine provinces (Table A10). When we exclude by-elections in KwaZulu-Natal, which has been particularly associated with political violence (footnote 16), the magnitude of the coefficient on the interaction term increases (column 4), but the basic pattern from the main results is evident throughout. We also drop by-elections from each calendar year at a time, and again the results are stable (Table A11). Our results are not driven by a particular region or period. Next, we vary control variables. We include fixed effects for the previous year's audit category, district instead of province fixed effects, month-of-year fixed effects, socio-economic characteristics of a municipality, and the number of days since the last regular municipal elections. Again, the basic pattern is not affected (Table A12). In case the probability of by-elections falling in the treatment window varies geographically, we also show our main results are robust to employing inverse probability weights, including based on interacted province and year fixed effects (Table A13).

We also explore effect heterogeneity. Voters face barriers to attribution when the party of the mayor changed during or since the end of the relevant financial year, or no party had a council majority. Their mobilization may depend on the competitiveness of a council, which we capture by splitting the sample at the median absolute seat difference between the first and second-largest party. As voter reactions may depend on the party in power, for instance due to varying loyalty or forms of attachment, we also interact with an indicator for ANC council 
majorities. To check if our results are amplified by local presence of media, we code whether a radio station or newspaper has its headquarters in a municipality. ${ }^{20} \mathrm{We}$ also measure the share of households in the municipality with internet access, a radio, or a television. Clientelistic relationships may dampen the effect of audits, and we proxy this with whether a municipality is officially classified as rural, and the presence of traditional authorities in a ward (De Kadt and Larreguy 2018). Finally, as salient ethnic cleavages may affect voting behavior, we condition on linguistic fractionalization. The coefficients on these three-way interaction terms are insignificant in eight out of ten regressions (Appendix Table A14). Curiously, internet penetration dampens the effect of our audit treatment, which is unexpected. The competitiveness of the local council boosts the impact of the audit treatment.

To check whether voters react to levels instead of trends, we use a different trichotomous measure to capture audit performance (Appendix Table A15). Here, we assign values of one for clean or unqualified (i.e., "good") audits, zero for a qualified outcome (the median category), and negative one for all other (i.e., "bad") outcomes. We also interact our windows indicator separately with "good" and "bad" audits (column 5). The results show no robust patterns. The release of audit results affects by-elections by revealing changes from previous performance.

Finally, we consider voter turnout: When we run our main models but replace our outcome variable with ward-level turnout, there are again no robust patterns (Appendix Table A16). Although our data do not allow us to investigate this, the electoral performance of parties may reflect mobilization differentials rather than voters switching their support (e.g., Holbein 2016, Justesen and Schulz-Herzenberg 2018).

\footnotetext{
${ }^{20}$ The near-universal availability of radio signal in South Africa means that a research design leveraging signal presence (akin to Larreguy et al. 2014) is not possible.
} 
One potential concern is that our sample of by-elections might not be representative. Although the timing of deaths in office is plausibly random, their frequency reflects local characteristics. We confirm this in an ancillary model, in a cross-section of municipalities, of overall frequency of councilor deaths in office (Appendix Table A17). Deaths in office are more likely where councils are larger (more eligible individuals), but less likely in municipalities with a major hospital (in one of the three highest-level categories: central, regional, or provincial tertiary). Yet more general health-related conditions, such as the prevalence of flush toilets or running water, are unrelated to the frequency of deaths. The fact that our main sample includes by-elections from 70 percent of all municipalities, and that larger councils and the presence of hospitals are generally offsetting conditions, suggest no major concerns over representativeness.

We next assess the micro-foundation of our model with survey data, examining effects of the 2018 audit release date at the individual-level, conditional on local audit trends. Although our outcome variable here is expressed evaluations of mayoral performance, rather than voting behavior, consistent ancillary results increase confidence in our by-election models. The South African Citizen Survey included questions on evaluations of mayoral performance from March through June 2018, overlapping with the May 23 release of the 2016-17 municipal audit report. We mirror our by-election research design, by interacting an indicator for the post-release period with a trichotomous measure reflecting the information for each respondent's municipality either declining, unchanged, or improving. We control for individual-level demographics, province fixed effects, and time trends (both linear and with third-order polynomials). We omit respondents from 26 municipalities with mayoral changes between the 2016 local elections and the period covered by the survey in 2018 , as these present a challenge to attribution. 
Comparing the periods before and after the release date, post-release mayoral evaluations are better on average by 0.18 (on a four-point approval scale) where the local audit outcome improved, and vice versa (column 1 in Table 2). When we enter positive and negative audit changes separately, the effect is driven more by improvements (column 2). The results are robust to inclusion of municipality fixed effects (column 3), a linear rather than cubic running variable (column 4), and alternate models using logistic (column 5) or ordered logit regression (column 6). A placebo test using evaluations of the national government as an outcome variable shows no significant interaction term (column 7). In supplementary models, we vary the length of the postrelease window from one to four weeks and find that the effect sizes decline monotonically over time (Table A18). These findings also provide reassurance about the external validity of our byelection results, as we identify the underpinning behavioral pattern more generally, in a representative survey and outside the specific context of by-elections.

Finally, we also investigate two different individual-level mechanisms through which the audit report treatment might operate: information salience and issue salience. Research in this area often faces difficulty disentangling whether treatments serve primarily to make individuals more aware of the information content itself, or rather to raise the salience of the relevant issues in their voting decisions. We thus assess whether post-release respondents are more likely to claim to have heard about their municipal audit results or problematic spending, and similarly if they are more likely to state that information about corruption and financial mismanagement is very important for their voting decisions. We find significant increases in information salience (Table A19), but no consistent relationship with issue salience (Table A20). In sum, audit information reaches voters in ways that are highly consistent with our by-election results, without necessarily affecting issue salience as well. 
Table 1: Audits and by-election vote shares

\begin{tabular}{|c|c|c|c|c|c|}
\hline & (1) & (2) & (3) & (4) & (5) \\
\hline Outcome change & $\begin{array}{l}0.007 \\
(0.023)\end{array}$ & $\begin{array}{l}-0.012 \\
(0.024)\end{array}$ & $\begin{array}{l}-0.017 \\
(0.013)\end{array}$ & $\begin{array}{l}-0.020 \\
(0.013)\end{array}$ & \\
\hline Window 90 & $\begin{array}{l}0.017 \\
(0.030)\end{array}$ & $\begin{array}{l}-0.002 \\
(0.032)\end{array}$ & $\begin{array}{l}-0.030^{* *} \\
(0.014)\end{array}$ & $\begin{array}{l}-0.037^{* *} \\
(0.016)\end{array}$ & $\begin{array}{l}-0.053 * * * \\
(0.018)\end{array}$ \\
\hline Window $90 \times$ Outcome change & & $\begin{array}{l}0.102 * \\
(0.058)\end{array}$ & $\begin{array}{l}0.056^{* *} * \\
(0.027)\end{array}$ & $\begin{array}{l}0.071 * * * \\
(0.025)\end{array}$ & \\
\hline Better & & & & & $\begin{array}{l}-0.027 \\
(0.018)\end{array}$ \\
\hline Window $90 \times$ Better & & & & & $\begin{array}{l}0.105^{* * *} * \\
(0.024)\end{array}$ \\
\hline Worse & & & & & $\begin{array}{l}0.010 \\
(0.023)\end{array}$ \\
\hline Window $90 \mathrm{x}$ Worse & & & & & $\begin{array}{l}-0.003 \\
(0.050)\end{array}$ \\
\hline Constant & $\begin{array}{l}0.649 * * * \\
(0.016)\end{array}$ & $\begin{array}{l}0.651 * * * \\
(0.016)\end{array}$ & $\begin{array}{l}0.070 * * \\
(0.029)\end{array}$ & $\begin{array}{l}0.112 * * * \\
(0.038)\end{array}$ & $\begin{array}{l}0.108 * * * \\
(0.038)\end{array}$ \\
\hline Window $90 \mid$ Outcome change $=1$ & & $\begin{array}{l}0.100^{*} \\
(0.059)\end{array}$ & $\begin{array}{l}0.027 \\
(0.028)\end{array}$ & $\begin{array}{l}0.034 \\
(0.027)\end{array}$ & \\
\hline Window $90 \mid$ Outcome change $=-1$ & & $\begin{array}{l}-0.103 \\
(0.072)\end{array}$ & $\begin{array}{l}-0.086 * * * \\
(0.032)\end{array}$ & $\begin{array}{l}-0.108 * * * \\
(0.032)\end{array}$ & \\
\hline Window $90 \mid$ Better $=1$ & & & & & $\begin{array}{l}0.052 * * \\
(0.024)\end{array}$ \\
\hline Window $90 \mid$ Worse $=1$ & & & & & $\begin{array}{l}-0.056 \\
(0.044)\end{array}$ \\
\hline Initial vote share (at last regular election) & No & No & Yes & Yes & Yes \\
\hline Province and year fixed effects & No & No & No & Yes & Yes \\
\hline Observations & 268 & 268 & 268 & 268 & 268 \\
\hline R-squared & 0.001 & 0.012 & 0.704 & 0.731 & 0.733 \\
\hline
\end{tabular}


Table 2: Audits and mayoral approval (survey data)

\begin{tabular}{|c|c|c|c|c|c|c|c|}
\hline & (1) & (2) & (3) & (4) & (5) & (6) & (7) \\
\hline Outcome change & $\begin{array}{l}0.018 \\
(0.053)\end{array}$ & & $\begin{array}{l}-0.552 \\
(0.576)\end{array}$ & $\begin{array}{l}0.018 \\
(0.053)\end{array}$ & $\begin{array}{l}0.081 \\
(0.128)\end{array}$ & $\begin{array}{l}0.034 \\
(0.103)\end{array}$ & $\begin{array}{l}0.108^{* *} \\
(0.044)\end{array}$ \\
\hline Post-release & $\begin{array}{l}0.002 \\
(0.141)\end{array}$ & $\begin{array}{l}0.015 \\
(0.141)\end{array}$ & $\begin{array}{l}0.055 \\
(0.142)\end{array}$ & $\begin{array}{l}-0.012 \\
(0.074)\end{array}$ & $\begin{array}{l}0.237 \\
(0.348)\end{array}$ & $\begin{array}{l}0.003 \\
(0.279)\end{array}$ & $\begin{array}{l}0.090 \\
(0.119)\end{array}$ \\
\hline Post-release $\mathrm{x}$ Outcome change & $\begin{array}{l}0.181^{* *} \\
(0.086)\end{array}$ & & $\begin{array}{l}0.172^{* *} \\
(0.083)\end{array}$ & $\begin{array}{l}0.176^{* *} \\
(0.086)\end{array}$ & $\begin{array}{l}-0.469 * * \\
(0.209)\end{array}$ & $\begin{array}{l}0.339 * * \\
(0.166)\end{array}$ & $\begin{array}{l}0.018 \\
(0.070)\end{array}$ \\
\hline Better & & $\begin{array}{l}0.125 \\
(0.109)\end{array}$ & & & & & \\
\hline Post-release x Better & & $\begin{array}{l}0.275 \\
(0.173)\end{array}$ & & & & & \\
\hline Worse & & $\begin{array}{l}0.030 \\
(0.066)\end{array}$ & & & & & \\
\hline Post-release $\mathrm{x}$ Worse & & $\begin{array}{l}-0.140 \\
(0.113) \\
\end{array}$ & & & & & \\
\hline Post-release $\mid$ Outcome change $=1$ & $\begin{array}{l}0.182 \\
(0.167)\end{array}$ & & $\begin{array}{l}0.228 \\
(0.167)\end{array}$ & $\begin{array}{l}0.164 \\
(0.126)\end{array}$ & $\begin{array}{l}-0.232 \\
0.413\end{array}$ & $\begin{array}{l}0.342 \\
(0.330)\end{array}$ & $\begin{array}{l}0.107 \\
(0.145)\end{array}$ \\
\hline Post-release $\mid$ Outcome change $=-1$ & $\begin{array}{l}-0.179 \\
(0.162)\end{array}$ & & $\begin{array}{l}-0.117 \\
(0.162)\end{array}$ & $\begin{array}{l}-0.189^{*} \\
(0.098)\end{array}$ & $\begin{array}{l}0.707 * \\
(0.398)\end{array}$ & $\begin{array}{l}-0.337 \\
(0.319)\end{array}$ & $\begin{array}{l}0.072 \\
(0.132)\end{array}$ \\
\hline Post-release $\mid$ Better $=1$ & & $\begin{array}{l}0.290 \\
(0.219)\end{array}$ & & & & & \\
\hline Post-release $\mid$ Worse $=1$ & & $\begin{array}{l}-0.125 \\
(0.176) \\
\end{array}$ & & & & & \\
\hline Approval measure & Mayor & Mayor & Mayor & Mayor & Mayor v. bad & Mayor & National gov. \\
\hline Model & Linear & Linear & Linear & Linear & Logistic & Ordered & Linear \\
\hline Fixed effects & Province & Province & Municipality & Province & Province & Province & Province \\
\hline Running variable & Nonlinear & Nonlinear & Nonlinear & Linear & Nonlinear & Nonlinear & Nonlinear \\
\hline Observations & 3,402 & 3,402 & 3,402 & 3,402 & 3,402 & 3,402 & 3,547 \\
\hline R-squared & 0.065 & 0.067 & 0.157 & 0.065 & & & 0.048 \\
\hline
\end{tabular}

Note: Standard errors in parentheses. All models also include controls for the running variable (cubic or linear); indicator for metropolitan, urban, or rural; age; education; income (with a separate dummy variable for no response); unemployment; gender; race. Sample restricted to respondents in municipalities without mayoral changes between the 2016 local elections and the period covered by the survey in 2018 (excluding 26 such municipalities).

$* * * \mathrm{p}<0.01, * * \mathrm{p}<0.05, * \mathrm{p}<0.1$ 


\section{Conclusions}

Recent research casts doubt on the potential of transparency to improve governance (e.g., Kosack and Fung 2014, Dunning et al. 2019a). Such findings should prompt systematic analysis of when and where information is most likely to improve political accountability. This article builds on a small number of prior studies to show that independent audit bodies can help voters hold those who govern to account, by releasing credible information at a time when it is most relevant: prior to an election. Our core result is that such timely and salient audit information shapes electoral behavior, with voters rewarding improvements and punishing stagnation or deteriorations by about 5 percentage points in the relevant party's vote share. Our study is the first to demonstrate electoral effects of audits that are at full scale in both information coverage and transmission.

Our results complement earlier observational studies on the effects of audits on mayoral elections in Brazil (Ferraz and Finan 2008), Mexico (Larreguy et al. 2014), and Puerto Rico (Bobonis et al. 2016), thus lending support to their generalizability beyond Latin America and the Caribbean, and beyond partial-scale audit programs. By examining a "hard case" with voting shaped by strong parties and racial identities (Ferree 2011), we also clarify the scope conditions of this work and demonstrate that the electoral effects of audits are not limited to individual accountability in systems where mayors are directly elected. Our micro-level results give confidence that we identify patterns in local political behavior more generally, beyond byelections alone, and further allow us to distinguish between information salience and issue salience. Our main research design is potentially replicable in other systems with by-elections, allowing researchers to probe external validity outside rare settings with randomly-timed audits.

Field experiments involving information campaigns by other actors that use audit findings have thus far not found similarly consistent impacts (e.g., Dunning et al. 2019a). Our 
discussion suggests this might be because such interventions cannot easily achieve the scale in transmission of audit bodies that reach voters organically through established channels. Moreover, non-governmental organizations or researchers that use audit information in their campaigns may struggle to project the same credibility as official audit bodies.

A major policy implication is that transparency and accountability initiatives by donors and international bodies should not neglect constitutional institutions and formal oversight practices. Many official bodies conduct regular and universal audits, often without the random selection or staggered timing that have enabled past research designs, thus highlighting the need for learning about the impacts of such information at full scale. Our study demonstrates important promise for scaling up the scope, capacity, and publicity of official auditors.

Our study also directly contributes to debates about voting patterns in South Africa. Using subnational and individual-level survey data, de Kadt and Lieberman (2020) find a robust negative association between basic service provision and electoral returns for the incumbent party. One explanation they offer is that those who receive basic services have closer contact with government, which increases opportunities to observe or perceive corruption. We show that credible and timely information suggesting localized corruption does affect the electoral fortunes of governing parties, independent from the underlying governance conditions themselves.

Perhaps most importantly, our results are good news for reformers: improved governance can produce electoral rewards. Although corrupt politicians may resist greater transparency in order to avoid sanction, these results suggest a more positive flipside that has received less attention in a literature that often emphasizes negative voter responses to poor performance. If these potential benefits were more widely known, this might increase political support for reforms that enhance transparency and accountability. 


\section{Acknowledgments:}

For helpful comments and assistance, we would like to thank Jim Alt, Ben Ansell, Thomas Bräuninger, Christian Breunig, Natalia Bueno, Hugh Cole, Paolo de Renzio, David Doyle, Andy Eggers, Aaron Erlich, Alice Evans, Karen Ferree, Omar García-Ponce, Mark Hallerberg, Robin Harding, David Heald, Macartan Humphreys, Ryan Jablonski, Eckhard Janeba, Stephen Kosack, Horacio Larreguy, Bob Mattes, Zeev Maoz, Nishendra Moodley, Aneesh Raghunandan, Vivek Ramkumar, Philip Rathgeb, Anselm Rink, Petra Schleiter, Kathryn Schneider, Collette SchulzHerzenberg, Daniel Sturm, Anjali Thomas, Christian Traxler, Jonathan Weigel, Martin J. Williams, Stephane Wolton, and Lauren Young. Trishna Kurian provided outstanding research assistance. Versions of this paper were presented at the 2017 MPSA, 2017 EPSA and 2017 and 2020 APSA annual meetings, the City of Cape Town, and seminars at Hertie, Konstanz, LSE, Mannheim, Oxford, Stellenbosch, and UC Davis. Our research into news coverage was possible due to database access in the National Library of South Africa. We would also like to thank staff at the Auditor-General and at the Electoral Commission, especially Stuart Murphy, for data and patiently answering our queries. We are indebted to Washeelah Kapery and Reza Omar for the data from the South African Citizen Survey. All interpretations and conclusions are entirely our own and should not be attributed to any of the above individuals or institutions.

\section{References}

Adida, Claire, Jessica Gottlieb, Eric Kramon, and Gwyneth McClendon. 2019. "Breaking the Clientelistic Voting Equilibrium: The Joint Importance of Salience and Coordination." Comparative Political Studies (forthcoming).

Alexander, Peter. 2010. "Rebellion of the Poor: South Africa's Service Delivery Protests - a Preliminary Analysis." Review of African Political Economy 37(123): 25-40. 
Arias, Eric, Pablo Balán, Horacio A. Larreguy, John Marshall, and Pablo Querubin. 2019a. "Information Provision, Voter Coordination, and Electoral Accountability: Evidence from Mexican Social Networks." American Political Science Review 113(2): 475-498.

Arias, Eric, Horacio A. Larreguy, John Marshall, and Pablo Querubin. 2019b. "When Does Information Increase Electoral Accountability? Lessons from a Field Experiment in Mexico." In Dunning et al. (Eds.), Information, Accountability, and Cumulative Learning: Lessons from Metaketa I. Cambridge, Cambridge University Press: 118-155.

Avis, Eric, Claudio Ferraz, and Frederico Finan. 2018. "Do Government Audits Reduce Corruption? Estimating the Impacts of Exposing Corrupt Politicians." Journal of Political Economy 126(5): 1912-1964.

Banerjee, Abhijit V., and Esther Duflo. 2009. "The Experimental Approach to Development Economics." Annual Review of Economics 1: 151-178.

Berliner, Daniel. 2017. "Sunlight or Window Dressing? Local Government Compliance with South Africa's Promotion of Access to Information Act." Governance 30(4): 641-661.

Boas, Taylor C., F. Daniel Hidalgo, and Marcus André Melo. 2019. "Norms versus Action: Why Voters Fail to Sanction Malfeasance in Brazil." American Journal of Political Science 63(2): $385-400$.

Bobonis, Gustavo J., Luis R. Cámara Fuertes, and Rainer Schwabe. 2016. "Monitoring Corruptible Politicians." American Economic Review 106(8): 2371-2405.

Botero, Sandra, Rodrigo Castro Cornejo, Laura Gamboa, Nara Pavao, and David W. Nickerson. 2015. "Says Who? An Experiment on Allegations of Corruption and Credibility of Sources." Political Research Quarterly 68(3): 493-504.

Boyne, George, Oliver James, Peter John, and Nicolai Petrovsky. 2009. "Democracy and Government Performance: Holding Incumbents Accountable in English Local Governments." Journal of Politics 71(4): 1273-1284. 
Brollo, Fernanda. 2010. "Who Is Punishing Corrupt Politicians: Voters or the Central Government? Evidence from the Brazilian Anticorruption Program." IGIER Working Paper. Buntaine, Mark T., Ryan Jablonski, Daniel L. Nielson, and Paula M. Pickering. 2018. "SMS Texts on Corruption Help Ugandan Voters Hold Elected Councilors Accountable at the Polls." Proceedings of the National Academy of Sciences 115(26): 6668-6673.

Chang, Eric C. C., Miriam A. Golden, and Seth J. Hill. 2010. "Legislative Malfeasance and Political Accountability." World Politics 62(2): 177-220.

Chong, Alberto, Ana L. De La O, Dean Karlan, and Leonard Wantchekon. 2015. "Does

Corruption Information Inspire the Fight or Quash the Hope? A Field Experiment in Mexico on Voter Turnout, Choice, and Party Identification." Journal of Politics 77(1): 55-71.

Cronin-Furman, Kate, and Milli Lake. 2018. "Ethics Abroad: Fieldwork in Fragile and Violent Contexts." PS: Political Science and Politics 51(3): 607-614.

Deaton, Angus, and Nancy Cartwright. 2018. "Understanding and Misunderstanding Randomized Controlled Trials." Social Science and Medicine 210: 2-21.

De Kadt, Daniel, and Evan S. Lieberman. 2020. "Nuanced Accountability: Voter Responses to Service Delivery in Southern Africa." British Journal of Political Science 50(1): 185-215.

De Kadt, Daniel, and Horacio A. Larreguy. 2018. "Agents of the Regime? Traditional Leaders and Electoral Politics in South Africa." Journal of Politics 80(2): 382-399.

De Vries, Catherine E., and Hector Solaz. 2017. "The Electoral Consequences of Corruption." Annual Review of Political Science 20: 391-408.

Dunning, Thad. 2012. Natural Experiments in the Social Sciences: A Design-Based Approach. Cambridge, Cambridge University Press.

Dunning, Thad, Guy Grossman, Macartan Humphreys, Susan D. Hyde, Craig McIntosh, and Gareth Nellis, eds. 2019a. Information, Accountability, and Cumulative Learning: Lessons from Metaketa I. Cambridge, Cambridge University Press. 
Dunning, Thad, et al. 2019b. "Voter Information Campaigns and Political Accountability:

Cumulative Findings from a Preregistered Meta-analysis of Coordinated Trials." Science Advances 5(7): eaaw2612.

Eggers, Andrew C. 2014. "Partisanship and Electoral Accountability: Evidence from the UK Expenses Scandal." Quarterly Journal of Political Science 9(4): 441-472.

Ferraz, Claudio, and Frederico Finan. 2008. "Exposing Corrupt Politicians: The Effects of Brazil's Publicly Released Audits on Electoral Outcomes." Quarterly Journal of Economics 123(2): 703-745.

Ferraz, Claudio, and Frederico Finan. 2011. "Electoral Accountability and Corruption: Evidence from the Audits of Local Governments." American Economic Review 101(4): 1274-1311.

Ferree, Karen E. 2011. Framing the Race in South Africa: The Political Origins of Racial Census Elections. New York, NY, Cambridge University Press.

Fiorina, Morris P. 1981. Retrospective Voting in American National Elections. New Haven, CT, Yale University Press.

Fung, Archon, Mary Graham, and David Weil. 2007. Full Disclosure: The Perils and Promise of Transparency. New York, NY, Cambridge University Press.

Gottlieb, Jessica. 2016. "Greater Expectations: A Field Experiment to Improve Accountability in Mali." American Journal of Political Science 60(1): 143-157.

Grossman, Guy, and Kristin Michelitch. 2018. "Information Dissemination, Competitive Pressure, and Politician Performance between Elections: A Field Experiment in Uganda." American Political Science Review 112(2): 280-301.

Healy, Andrew, and Neil Malhotra. 2013. "Retrospective Voting Reconsidered." Annual Review of Political Science 16: 285-306.

Holbein, John. 2016. "Left Behind? Citizen Responsiveness to Government Performance Information." American Political Science Review 110(2): 353-368. 
Humphreys, Macartan, and Jeremy Weinstein. 2012. "Policing Politicians: Citizen Empowerment and Political Accountability in Uganda." Mimeo.

Johnson, Jeremy B. 2018. "Protecting the Community: Lessons from the Montana Flyer Project." PS: Political Science and Politics 51(3): 615-619.

Jones, Benjamin F., and Benjamin A. Olken. 2005. "Do Leaders Matter? National Leadership and Growth Since World War II." Quarterly Journal of Economics 120(3): 835-864.

Justesen, Mogens K., and Collette Schulz-Herzenberg. 2018. "The Decline of the African National Congress in South Africa's 2016 Municipal Elections." Journal of Southern African Studies 44(6): 1133-1151.

Kosack, Stephen, and Archon Fung. 2014. "Does Transparency Improve Governance?" Annual Review of Political Science 17: 65-87.

Kroth, Verena, Valentino Larcinese, and Joachim Wehner. 2016. "A Better Life for All? Democratization and Electrification in Post-Apartheid South Africa." Journal of Politics 78(3): 774-791.

Larreguy, Horacio A., John Marshall, and James M. Snyder, Jr. 2014. "Revealing Malfeasance: How Local Media Facilitates Electoral Sanctioning of Mayors in Mexico." NBER Working Paper 20697.

Lieberman, Evan S., Daniel N. Posner, and Lily L.Tsai. 2014. "Does Information Lead to More Active Citizenship? Evidence from an Education Intervention in Rural Kenya." World Development 60: 69-83.

Mansuri, Ghazala, and Vijayendra Rao. 2013. Localizing Development: Does Participation Work? Washington, DC, World Bank.

Mattes, Robert. 2008. "South Africans' Participation in Local Politics and Government." Transformation: Critical Perspectives on Southern Africa 66/67: 117-141. 
McCombs, Maxwell E., and Donald L. Shaw. (1972). "The Agenda-Setting Function of Mass Media." Public Opinion Quarterly 36(2): 176-187.

O'Donnell, Guillermo. 1998. "Horizontal Accountability in New Democracies." Journal of Democracy 9(3): 112-126.

Olver, Crispian. 2017. How to Steal a City: The Battle for Nelson Mandela Bay. Jeppestown, Jonathan Ball Publishers.

Przeworski, Adam, Susan C. Stokes, and Bernard Manin, eds. 1999. Democracy, Accountability, and Representation. Cambridge, Cambridge University Press.

Schwindt-Bayer, Leslie, and Margit Tavits. 2016. Clarity of Responsibility, Accountability and Corruption. Cambridge, Cambridge University Press.

Weitz-Shapiro, Rebecca, and Matthew S. Winters. 2016. "Can Citizens Discern? Information Credibility, Political Sophistication, and the Punishment of Corruption in Brazil." Journal of Politics 79(1): 60-74.

Winters, Matthew S., and Rebecca Weitz-Shapiro. 2013. "Lacking Information or Condoning Corruption: When Do Voters Support Corrupt Politicians?" Comparative Politics 45(4): 418436.

\section{Biographical Statements:}

Daniel Berliner is Associate Professor of Political Science and Public Policy at the London School of Economics and Political Science, London, United Kingdom. Joachim Wehner is Associate Professor in Public Policy at the London School of Economics and Political Science, London, United Kingdom. 
Online Appendix for "Audits for Accountability: Evidence from Municipal By-Elections in South Africa" 
Table A1: Selected features of studies of the electoral impacts of audit information Table A2: Official descriptions of audit outcomes

Table A3: Overview of municipal audit outcomes for financial years 2006-7 to 2013-14

Table A4: By-elections from 2007 to 2015 by type of triggering event

Table A5: Balance statistics

Table A6: Heckman selection-correction model

Table A7: Different time windows

Table A8: Sample restricted to by-elections within 90 days of a release date

Table A9: Alternative standard errors

Table A10: Excluding by-elections in individual provinces

Table A11: Excluding by-elections in individual calendar years

Table A12: Additional controls

Table A13: Inverse probability weighting

Table A14: Context conditions

Table A15: Audit outcome in levels

Table A16: Turnout as dependent variable

Table A17: Frequency of by-elections triggered by death across municipalities

Table A18: Different time windows (survey data)

Table A19: Respondents who have heard of municipal audits (survey data)

Table A20: Respondents who say corruption and financial mismanagement information is very important in voting (survey data)

Figure A1: Media attention to municipal audits spikes after the release of the Auditor-General's report (overlay version)

Figure A2: Eyewitness News municipal audits portal

Figure A3: Example of ANC-run municipality advertising audit outcomes

Figure A4: Example of DA advertising municipal audit outcomes

Figure A5: Treatment assignment of by-elections

Figure A6: McCrary sorting tests

Figure A7: Overview of municipal audit outcomes for financial years 2006-7 to 2013-14 (line graph version)

Figure A8: Use of color-coding and arrows in audit reports

Figure A9: Graph of main regression results

Data appendix

Table A21: Summary statistics (by-elections data)

Table A22: Summary statistics (survey data) 
Table A1: Selected features of studies of the electoral impacts of audit information

\begin{tabular}{|c|c|c|c|c|}
\hline Study & Auditor & Scale of information & Scale of transmission & Core results \\
\hline $\begin{array}{l}\text { Ferraz and Finan (2008) } \\
\text { Setting: Brazil } \\
\text { Type: Natural experiment }\end{array}$ & $\begin{array}{l}\text { National: Comptroller } \\
\text { General of the Union } \\
\text { (Controladoria-Geral da } \\
\text { União, CGU) }\end{array}$ & $\begin{array}{l}\text { Partial: CGU audits federal } \\
\text { transfers to municipalities. It } \\
\text { randomly samples municipalities } \\
\text { for audit. }\end{array}$ & $\begin{array}{l}\text { Public and organic: Natural } \\
\text { diffusion via established } \\
\text { channels (e.g., media). }\end{array}$ & $\begin{array}{l}\text { Poor audit outcomes reduce the reelection } \\
\text { chances of incumbent mayors, especially } \\
\text { in municipalities with local radio stations. }\end{array}$ \\
\hline $\begin{array}{l}\text { Larreguy et al. (2014) } \\
\text { Setting: Mexico } \\
\text { Type: Quasi-experiment* }\end{array}$ & $\begin{array}{l}\text { National: Superior Audit } \\
\text { Office of the Federation } \\
\text { (Auditoría Superior de la } \\
\text { Federación, ASF) }\end{array}$ & $\begin{array}{l}\text { Partial: The ASF audits federal } \\
\text { grants from the Fund for Social } \\
\text { Infrastructure (FISM). It selects } \\
\text { municipalities in each state to be } \\
\text { audited according to fixed criteria. }\end{array}$ & $\begin{array}{l}\text { Public and organic: Natural } \\
\text { diffusion via established } \\
\text { channels (e.g., media). }\end{array}$ & $\begin{array}{l}\text { Voters punish the party of mayors } \\
\text { responsible for poor audit outcomes, but } \\
\text { only in electoral precincts where local } \\
\text { media stations transmit from within the } \\
\text { municipality. }\end{array}$ \\
\hline $\begin{array}{l}\text { Chong et al. (2015) } \\
\text { Setting: Mexico } \\
\text { Type: Field experiment }\end{array}$ & $\begin{array}{l}\text { National: Superior Audit } \\
\text { Office of the Federation } \\
\text { (Auditoría Superior de la } \\
\text { Federación, ASF) }\end{array}$ & $\begin{array}{l}\text { Partial: The ASF audits federal } \\
\text { grants from the Fund for Social } \\
\text { Infrastructure (FISM). It selects } \\
\text { municipalities in each state to be } \\
\text { audited according to fixed criteria. }\end{array}$ & $\begin{array}{l}\text { Private and induced: Flyers } \\
\text { distributed in collaboration } \\
\text { with a research } \\
\text { organization (Innovations } \\
\text { for Poverty Action). }\end{array}$ & $\begin{array}{l}\text { Poor audit performance decreases } \\
\text { incumbent party support in local } \\
\text { elections, decreases voter turnout and } \\
\text { support for the challenger party, and } \\
\text { erodes partisan attachments. }\end{array}$ \\
\hline $\begin{array}{l}\text { Bobonis et al. (2016) } \\
\text { Setting: Puerto Rico (US) } \\
\text { Type: Quasi-experiment* }\end{array}$ & $\begin{array}{l}\text { Subnational: Office of the } \\
\text { Comptroller General of } \\
\text { Puerto Rico (Oficina del } \\
\text { Contralor de Puerto Rico, } \\
\text { OCPR) }\end{array}$ & $\begin{array}{l}\text { Partial: All municipalities should be } \\
\text { audited every other fiscal year, } \\
\text { following a prespecified order, but } \\
\text { audit cycles can take longer due to } \\
\text { resource constraints. }\end{array}$ & $\begin{array}{l}\text { Public and organic: Natural } \\
\text { diffusion via established } \\
\text { channels (e.g., media). }\end{array}$ & $\begin{array}{l}\text { Audit performance is better in } \\
\text { municipalities with pre-election audits, } \\
\text { where it improves mayors' reelection } \\
\text { rates. Good performance is not sustained } \\
\text { in subsequent audits. }\end{array}$ \\
\hline $\begin{array}{l}\text { Arias et al. }(2019 a, 2019 b)^{* *} \\
\text { Setting: Mexico } \\
\text { Type: Field experiment }\end{array}$ & $\begin{array}{l}\text { National: Superior Audit } \\
\text { Office of the Federation } \\
\text { (Auditoría Superior de la } \\
\text { Federación, ASF) }\end{array}$ & $\begin{array}{l}\text { Partial: The ASF audits federal } \\
\text { grants from the Fund for Social } \\
\text { Infrastructure (FISM). It selects } \\
\text { municipalities in each state to be } \\
\text { audited according to fixed criteria. }\end{array}$ & $\begin{array}{l}\text { Private (plus weakly } \\
\text { public) and induced: } \\
\text { Leaflets distributed by an } \\
\text { NGO (Borde Político); in a } \\
\text { "public treatment" arm, } \\
\text { loudspeakers announced } \\
\text { the distribution. }\end{array}$ & $\begin{array}{l}\text { Both good as well as poor audit } \\
\text { performance increase turnout and } \\
\text { electoral support, on average, for the } \\
\text { incumbent party. A related study found } \\
\text { these effects vary by communities' social } \\
\text { network connectedness. }\end{array}$ \\
\hline $\begin{array}{l}\text { Boas et al. }(2019)^{* *} \\
\text { Setting: Pernambuco (Brazil) } \\
\text { Type: Field experiment }\end{array}$ & $\begin{array}{l}\text { Subnational: State } \\
\text { Accounts Court of } \\
\text { Pernambuco (Tribunal de } \\
\text { Contas do Estado de } \\
\text { Pernambuco, TCE-PE) }\end{array}$ & $\begin{array}{l}\text { Full: Routine annual audits of } \\
\text { municipal accounts. Most audits are } \\
\text { completed within three years. }\end{array}$ & $\begin{array}{l}\text { Private and induced: Flyers } \\
\text { handed out by enumerators } \\
\text { during the baseline survey. }\end{array}$ & $\begin{array}{l}\text { Audit information has no effect on self- } \\
\text { reported voting behavior in actual } \\
\text { municipal elections. In a vignette } \\
\text { experiment, respondents are less willing } \\
\text { to vote for a hypothetical mayor with } \\
\text { poor audit results. }\end{array}$ \\
\hline $\begin{array}{l}\text { Buntaine et al. }(2018)^{* *} \\
\text { Setting: Uganda } \\
\text { Type: Field experiment }\end{array}$ & $\begin{array}{l}\text { National: Office of the } \\
\text { Auditor General (OAG) }\end{array}$ & $\begin{array}{l}\text { Full: Routine annual audits of } \\
\text { district council accounts, typically } \\
\text { completed within a year. }\end{array}$ & $\begin{array}{l}\text { Private and induced: SMS } \\
\text { messages sent out in } \\
\text { cooperation with a local } \\
\text { NGO (Twaweza). }\end{array}$ & $\begin{array}{l}\text { Recipients of SMS messages describing } \\
\text { more (fewer) irregularities than expected } \\
\text { reported voting for incumbent councilors } \\
\text { less (more) often. The messages have no } \\
\text { effect on reported voting for incumbent } \\
\text { council chairs. }\end{array}$ \\
\hline $\begin{array}{l}\text { This study } \\
\text { Setting: South Africa } \\
\text { Type: Natural experiment }\end{array}$ & $\begin{array}{l}\text { National: Auditor General } \\
\text { of South Africa (AGSA) }\end{array}$ & $\begin{array}{l}\text { Full: Routine annual audits of } \\
\text { municipal accounts, typically } \\
\text { completed within a year. }\end{array}$ & $\begin{array}{l}\text { Public and organic: Natural } \\
\text { diffusion via established } \\
\text { channels (e.g., media). }\end{array}$ & $\begin{array}{l}\text { The responsible mayor's party is } \\
\text { rewarded for improvements in audit } \\
\text { results and punished for both stagnation } \\
\text { and deteriorations. }\end{array}$ \\
\hline
\end{tabular}

assigned treatments. ** These studies were part of or are related to the Metaketa I initiative (Dunning et al. 2019a). 
Table A2: Official descriptions of audit outcomes

\begin{tabular}{|c|c|}
\hline Audit outcome & Description \\
\hline Clean & $\begin{array}{l}\text { The financial statements are free from material misstatements (in other words, a financially unqualified audit opinion) and there are } \\
\text { no material findings on reporting on performance objectives or non-compliance with legislation. }\end{array}$ \\
\hline Unqualified & $\begin{array}{l}\text { The financial statements contain no material misstatements. Unless we express a clean audit outcome, findings have been raised on } \\
\text { either reporting on predetermined objectives or non-compliance with legislation, or both these aspects. }\end{array}$ \\
\hline Qualified & $\begin{array}{l}\text { The financial statements contain material misstatements in specific amounts, or there is insufficient evidence for us to conclude that } \\
\text { specific amounts included in the financial statements are not materially misstated. }\end{array}$ \\
\hline Adverse & $\begin{array}{l}\text { The financial statements contain material misstatements that are not confined to specific amounts, or the misstatements represent a } \\
\text { substantial portion of the financial statements. }\end{array}$ \\
\hline Disclaimer & $\begin{array}{l}\text { The auditee provided insufficient evidence in the form of documentation on which to base an audit opinion. The lack of sufficient } \\
\text { evidence is not confined to specific amounts or represents a substantial portion of the information contained in the financial } \\
\text { statements. }\end{array}$ \\
\hline Outstanding & Audit not finalized at legislated date. \\
\hline
\end{tabular}


Table A3: Overview of municipal audit outcomes for financial years 2006-7 to 2013-14

\begin{tabular}{llllllll}
\hline Financial year & Release date & Clean & Unqualified & Qualified & Adverse & Disclaimer & Outstanding \\
\hline $2006-7$ & Feb. 10, 2009 & 0.008 & 0.161 & 0.246 & 0.089 & 0.458 & 0.038 \\
$2007-8$ & July 10, 2009 & 0.017 & 0.270 & 0.197 & 0.039 & 0.330 & 0.146 \\
$2008-9$ & June 7, 2010 & 0.013 & 0.340 & 0.179 & 0.026 & 0.311 & 0.132 \\
$2009-10$ & June 29, 2011 & 0.017 & 0.400 & 0.179 & 0.030 & 0.217 & 0.157 \\
$2010-11$ & July 23, 2012 & 0.034 & 0.389 & 0.184 & 0.017 & 0.222 & 0.154 \\
$2011-12$ & Aug. 13, 2013 & 0.021 & 0.342 & 0.248 & 0.004 & 0.299 & 0.085 \\
$2012-13$ & July 30, 2014 & 0.073 & 0.329 & 0.295 & 0.034 & 0.222 & 0.047 \\
$2013-14$ & June 3, 2015 & 0.120 & 0.389 & 0.248 & 0.004 & 0.201 & 0.038 \\
\hline
\end{tabular}

Note: Audit findings are ordered from best ("clean") to worst ("disclaimer"), followed by "Outstanding," referring to cases where municipalities did not even submit the required documentation to the Auditor-General. There was no release in either 2007 or 2008, and a new format with more explicitly comparative tables was introduced for annual municipal audit reports published from 2009 onwards. Release dates were provided by the Auditor-General of South Africa and double checked against press reports and official press releases. We use audit outcomes as contemporaneously released and reported, not any updates made subsequently in rare cases. Note that the February 2009 release of the 2006-2007 audit is not treated as a "post-release window" in our dataset, since publication had been delayed by an extra year and was no longer timely. 
Table A4: By-elections from 2007 to 2015 by type of triggering event

\begin{tabular}{lll}
\hline By-election due to & Frequency & Proportion in 90-day window \\
\hline Resignation & 363 & 0.154 \\
Death & 347 & 0.187 \\
Expulsion & 120 & 0.217 \\
Termination & 82 & 0.207 \\
Higher office & 33 & 0.364 \\
Other & 4 & 0.250 \\
\hline
\end{tabular}

Note: We have excluded 31 by-elections (arising from only four distinct incidents) triggered by the dissolution of an entire municipal council, requiring all seats to be re-elected at once. 


\section{Table A5: Balance statistics}

All by-elections (excl. full council dismissal) By-elections due to death only

\begin{tabular}{|c|c|c|c|c|c|c|}
\hline Variable & $\begin{array}{l}\text { Mean } \\
\text { outside } \\
\text { window }\end{array}$ & $\begin{array}{l}\text { Mean } \\
\text { inside } \\
\text { window }\end{array}$ & p-value & $\begin{array}{l}\text { Mean } \\
\text { outside } \\
\text { window }\end{array}$ & $\begin{array}{l}\text { Mean } \\
\text { inside } \\
\text { window }\end{array}$ & p-value \\
\hline Audit outcome better & 0.312 & 0.267 & 0.238 & 0.261 & 0.277 & 0.803 \\
\hline Audit outcome change & 0.156 & 0.148 & 0.877 & 0.127 & 0.169 & 0.614 \\
\hline Audit outcome worse & 0.156 & 0.119 & 0.194 & 0.135 & 0.108 & 0.545 \\
\hline Audit: Adverse & 0.008 & 0.017 & 0.411 & 0.008 & 0.046 & 0.161 \\
\hline Audit: Clean & 0.077 & 0.107 & 0.241 & 0.057 & 0.031 & 0.323 \\
\hline Audit: Disclaimer & 0.259 & 0.249 & 0.772 & 0.308 & 0.200 & $0.066^{*}$ \\
\hline Audit: Outstanding & 0.059 & 0.079 & 0.370 & 0.049 & 0.077 & 0.434 \\
\hline Audit: Qualified & 0.266 & 0.198 & $0.047 * *$ & 0.251 & 0.246 & 0.936 \\
\hline Audit: Unqualified & 0.325 & 0.350 & 0.534 & 0.324 & 0.400 & 0.267 \\
\hline Barriers to attribution & 0.320 & 0.226 & $0.044 * *$ & 0.296 & 0.215 & 0.313 \\
\hline By-election is uncontested & 0.089 & 0.090 & 0.945 & 0.097 & 0.154 & 0.250 \\
\hline Educational attendance & 0.504 & 0.530 & 0.127 & 0.554 & 0.552 & 0.944 \\
\hline First and second-largest party seat difference & 26.924 & 27.593 & 0.696 & 25.317 & 25.523 & 0.936 \\
\hline Governing party (of municipality) not running & 0.032 & 0.017 & 0.191 & 0.028 & 0.015 & 0.489 \\
\hline Governing party is ANC & 0.783 & 0.774 & 0.796 & 0.826 & 0.785 & 0.469 \\
\hline Largest party seat share & 0.684 & 0.692 & 0.522 & 0.697 & 0.713 & 0.394 \\
\hline Linguistic fractionalization & 2.102 & 2.153 & 0.685 & 2.050 & 2.130 & 0.708 \\
\hline Log average income & 10.417 & 10.385 & 0.501 & 10.278 & 10.300 & 0.766 \\
\hline Log population & 12.245 & 12.307 & 0.552 & 12.161 & 12.082 & 0.594 \\
\hline Media outlet has office in municipality & 0.459 & 0.492 & 0.442 & 0.413 & 0.446 & 0.634 \\
\hline Metropolitan municipality & 0.180 & 0.158 & 0.478 & 0.130 & 0.077 & 0.186 \\
\hline Number of parties contesting by-election & 3.069 & 2.774 & $0.004 * * *$ & 2.976 & 2.662 & $0.082 *$ \\
\hline Original election ANC seat share & 0.637 & 0.634 & 0.862 & 0.645 & 0.651 & 0.820 \\
\hline Original election governing party vote share & 0.641 & 0.620 & 0.399 & 0.677 & 0.705 & 0.417 \\
\hline Original election turnout & 0.546 & 0.573 & $0.001 * * *$ & 0.535 & 0.556 & 0.153 \\
\hline Original election winner is $\mathrm{ANC}$ & 0.694 & 0.638 & 0.165 & 0.777 & 0.800 & 0.690 \\
\hline Original election winning party vote share & 0.719 & 0.738 & 0.185 & 0.720 & 0.747 & 0.243 \\
\hline Proportion with flush toilets & 0.577 & 0.532 & 0.100 & 0.517 & 0.493 & 0.594 \\
\hline Proportion with internet & 0.295 & 0.294 & 0.883 & 0.283 & 0.280 & 0.839 \\
\hline Proportion with matric & 0.342 & 0.336 & 0.550 & 0.329 & 0.330 & 0.983 \\
\hline Proportion with radio & 0.660 & 0.655 & 0.483 & 0.655 & 0.651 & 0.686 \\
\hline Proportion with water at home & 0.676 & 0.652 & 0.319 & 0.618 & 0.661 & 0.253 \\
\hline White population proportion & 0.080 & 0.075 & 0.427 & 0.068 & 0.063 & 0.587 \\
\hline
\end{tabular}

Note: $* * * \mathrm{p}<0.01, * * \mathrm{p}<0.05, * \mathrm{p}<0.1$ 
Table A6: Heckman selection-correction model

\begin{tabular}{lll}
\hline & $\mathbf{( 1 )}$ & $\mathbf{( 2 )}$ \\
\hline Dependent variable & Vote share & Contested \\
\hline Biggest party seat share (on council) & & $-5.749 * * *$ \\
Outcome change & & $(0.875)$ \\
Window 90 & -0.014 & -0.213 \\
& $(0.025)$ & $(0.199)$ \\
Window 90 x Outcome change & -0.025 & $-0.491 * *$ \\
& $(0.036)$ & $(0.242)$ \\
Constant & $0.120^{* *}$ & $0.632^{* *}$ \\
& $(0.058)$ & $(0.251)$ \\
$\lambda$ (inverse Mills) & $0.620^{* * *}$ & $5.623 * * *$ \\
& $(0.017)$ & $(0.712)$ \\
$\rho$ & $0.172 * * *$ & \\
$\sigma$ & $(0.026)$ & \\
Wald $X^{2}$ test of independent equations $(\rho=0)$ & 0.683 & \\
\hline Observations & 0.251 & \\
Censored observations & $28.79 * * *$ & \\
Uncensored observations & 303 & \\
\hline
\end{tabular}

Note: Heckman selection-correction model for the vote share model in column 2 of Table 1 and selection on whether more than one party participated in the by-election, with standard errors clustered by by-election date in parentheses. The estimated correlation between the errors in the selection and vote share equations is $\rho$ and the standard error of the residual in the vote share equation is $\sigma$. The estimate of the selection hazard is $\lambda=\rho \sigma$ and its significance suggests a meaningful selection effect in the vote share model. Including the initial vote share at the last regular election results in the seat share of the biggest party no longer being significant in the selection equation. Models with fixed effects do not converge.

$* * * \mathrm{p}<0.01, * * \mathrm{p}<0.05, * \mathrm{p}<0.1$ 
Table A7: Different time windows

\begin{tabular}{|c|c|c|c|c|c|}
\hline & (1) & (2) & (3) & (4) & \\
\hline Outcome change & $\begin{array}{l}-0.008 \\
(0.012)\end{array}$ & $\begin{array}{l}-0.017 \\
(0.013)\end{array}$ & $\begin{array}{l}-0.020 \\
(0.013)\end{array}$ & $\begin{array}{l}-0.024 \\
(0.016)\end{array}$ & $\begin{array}{l}0.188 * * \\
(0.074)\end{array}$ \\
\hline Window 30 & $\begin{array}{l}-0.087^{*} \\
(0.044)\end{array}$ & & & & \\
\hline Window $30 \times$ Outcome change & $\begin{array}{l}0.127 * \\
(0.072)\end{array}$ & & & & \\
\hline Window 60 & & $\begin{array}{l}-0.041 * * \\
(0.018)\end{array}$ & & & \\
\hline Window $60 \times$ Outcome change & & $\begin{array}{l}0.079 * * \\
(0.031)\end{array}$ & & & \\
\hline Window 90 & & & $\begin{array}{l}-0.037 * * \\
(0.016)\end{array}$ & & \\
\hline Window 90 x Outcome change & & & $\begin{array}{l}0.071 * * * \\
(0.025)\end{array}$ & & \\
\hline Window 120 & & & & $\begin{array}{l}0.003 \\
(0.015)\end{array}$ & \\
\hline Window $120 \times$ Outcome change & & & & $\begin{array}{l}0.042 * * \\
(0.021)\end{array}$ & \\
\hline Days since last release $(\log )$ & & & & & $\begin{array}{l}0.015 \\
(0.014)\end{array}$ \\
\hline Days since last release (log) x Outcome change & & & & & $\begin{array}{l}-0.038 * * \\
(0.015)\end{array}$ \\
\hline Window $\mathrm{x} \mid$ Outcome change $=1$ & $\begin{array}{l}0.040 \\
(0.039)\end{array}$ & $\begin{array}{l}0.038 \\
(0.032)\end{array}$ & $\begin{array}{l}0.034 \\
(0.027)\end{array}$ & $\begin{array}{l}0.045^{*} \\
(0.024)\end{array}$ & \\
\hline Window $\mathrm{x}$ | Outcome change $=-1$ & $\begin{array}{l}-0.214^{*} \\
(0.114)\end{array}$ & $\begin{array}{l}-0.120^{* * *} \\
(0.039)\end{array}$ & $\begin{array}{l}-0.108^{* * *} \\
(0.032)\end{array}$ & $\begin{array}{l}-0.039 \\
(0.027)\end{array}$ & \\
\hline Initial vote share (at last regular election) & Yes & Yes & Yes & Yes & Yes \\
\hline Province and year fixed effects & Yes & Yes & Yes & Yes & Yes \\
\hline Observations & 268 & 268 & 268 & 268 & 209 \\
\hline R-squared & 0.727 & 0.730 & 0.731 & 0.728 & 0.711 \\
\hline
\end{tabular}

Note: Standard errors clustered by by-election date in parentheses.

$* * * \mathrm{p}<0.01, * * \mathrm{p}<0.05, * \mathrm{p}<0.1$ 
Table A8: Sample restricted to by-elections within 90 days of a release date

\begin{tabular}{|c|c|c|c|c|c|}
\hline & (1) & (2) & (3) & (4) & (5) \\
\hline Outcome change & $\begin{array}{l}0.014 \\
(0.041)\end{array}$ & $\begin{array}{l}-0.043 \\
(0.054)\end{array}$ & $\begin{array}{l}-0.033 * \\
(0.018)\end{array}$ & $\begin{array}{l}-0.040 \\
(0.026)\end{array}$ & \\
\hline Window 90 & $\begin{array}{l}-0.019 \\
(0.039)\end{array}$ & $\begin{array}{l}-0.038 \\
(0.037)\end{array}$ & $\begin{array}{l}-0.063 * * * \\
(0.016)\end{array}$ & $\begin{array}{l}-0.054 * * * \\
(0.017)\end{array}$ & $\begin{array}{l}-0.084 * * * \\
(0.019)\end{array}$ \\
\hline Window $90 \times$ Outcome change & & $\begin{array}{l}0.133^{*} \\
(0.076)\end{array}$ & $\begin{array}{l}0.075 * * \\
(0.030)\end{array}$ & $\begin{array}{l}0.096 * * * \\
(0.033)\end{array}$ & \\
\hline Better & & & & & $\begin{array}{l}-0.078 * * * \\
(0.027)\end{array}$ \\
\hline Window 90 x Better & & & & & $\begin{array}{l}0.146^{* * *} \\
(0.029)\end{array}$ \\
\hline Worse & & & & & $\begin{array}{l}-0.006 \\
(0.043)\end{array}$ \\
\hline Window $90 \mathrm{x}$ Worse & & & & & $\begin{array}{l}-0.016 \\
(0.062)\end{array}$ \\
\hline Constant & $\begin{array}{l}0.684 * * * \\
(0.026)\end{array}$ & $\begin{array}{l}0.688 * * * \\
(0.024)\end{array}$ & $\begin{array}{l}0.130 * * \\
(0.060)\end{array}$ & $\begin{array}{l}0.188 * * * \\
(0.066)\end{array}$ & $\begin{array}{l}0.199 * * * \\
(0.065)\end{array}$ \\
\hline Window $90 \mid$ Outcome change $=1$ & & $\begin{array}{l}0.095 \\
0.085\end{array}$ & $\begin{array}{l}0.012 \\
(0.030)\end{array}$ & $\begin{array}{l}0.042 \\
(0.032)\end{array}$ & \\
\hline Window $90 \mid$ Outcome change $=-1$ & & $\begin{array}{l}-0.171 * * \\
(0.083)\end{array}$ & $\begin{array}{l}-0.138^{* * *} \\
(0.038)\end{array}$ & $\begin{array}{l}-0.149 * * * \\
(0.042)\end{array}$ & \\
\hline Window $90 \mid$ Better $=1$ & & & & & $\begin{array}{l}0.062 * * \\
(0.029)\end{array}$ \\
\hline Window $90 \mid$ Worse $=1$ & & & & & $\begin{array}{l}-0.100 * \\
(0.056)\end{array}$ \\
\hline Initial vote share (at last regular election) & No & No & Yes & Yes & Yes \\
\hline Province and year fixed effects & No & No & No & Yes & Yes \\
\hline Observations & 104 & 104 & 104 & 104 & 104 \\
\hline R-squared & 0.003 & 0.039 & 0.714 & 0.777 & 0.781 \\
\hline
\end{tabular}

Note: Standard errors clustered by by-election date in parentheses. This regression table replicates the analysis in Table 1 with a sample restricted to by-elections within 90 days prior to and after the mid-year release dates specified in Table A2.

$* * * \mathrm{p}<0.01, * * \mathrm{p}<0.05, * \mathrm{p}<0.1$ 
Table A9: Alternative standard errors

\begin{tabular}{lllll}
\hline & $(\mathbf{1})$ & $\mathbf{( 2 )}$ & $\mathbf{( 3 )}$ & $\mathbf{( 4 )}$ \\
\hline Outcome change & -0.020 & -0.020 & -0.020 & -0.020 \\
Window 90 & $(0.013)$ & $(0.014)$ & $(0.013)$ & $(0.013)$ \\
& $-0.037^{* *}$ & $-0.037^{*}$ & $-0.037^{*}$ & $-0.037^{*}$ \\
Window 90 x Outcome change & $(0.015)$ & $(0.021)$ & $(0.022)$ & $(0.019)$ \\
& $0.071^{* * *}$ & $0.071^{* *}$ & $0.071^{* *}$ & $0.071^{* *}$ \\
\hline Initial vote share (at last regular election) & $(0.021)$ & $(0.033)$ & $(0.028)$ & $(0.028)$ \\
Province and year fixed effects & Yes & Yes & Yes & Yes \\
Observations & Yes & Yes & Yes & Yes \\
R-squared & 268 & 268 & 268 & 268 \\
\hline Note: Main modes & 0.731 & 0.731 & 0.731 & 0.731
\end{tabular}

Note: Main model (column 4 in Table 1) with alternative standard errors in parentheses: two-way

clustered by date and municipality (column 1), ordinary (column 2), bootstrapped with 1000 repetitions (column 3), and bootstrapped with 1000 repetitions and clustered by by-election date (column 4 ).

$* * * \mathrm{p}<0.01, * * \mathrm{p}<0.05, * \mathrm{p}<0.1$ 
Table A10: Excluding by-elections in individual provinces

\begin{tabular}{|c|c|c|c|c|c|c|c|c|c|}
\hline & (1) & (2) & (3) & (4) & (5) & (6) & (7) & (8) & (9) \\
\hline Outcome change & $\begin{array}{l}-0.011 \\
(0.015)\end{array}$ & $\begin{array}{l}-0.021 \\
(0.014)\end{array}$ & $\begin{array}{l}-0.020 \\
(0.014)\end{array}$ & $\begin{array}{l}-0.032 * * \\
(0.016)\end{array}$ & $\begin{array}{l}-0.017 \\
(0.014)\end{array}$ & $\begin{array}{l}-0.017 \\
(0.013)\end{array}$ & $\begin{array}{l}-0.025^{*} \\
(0.013)\end{array}$ & $\begin{array}{l}-0.020 \\
(0.014)\end{array}$ & $\begin{array}{l}-0.018 \\
(0.014)\end{array}$ \\
\hline Window 90 & $\begin{array}{l}-0.034^{* *} \\
(0.014)\end{array}$ & $\begin{array}{l}-0.040 * * \\
(0.017)\end{array}$ & $\begin{array}{l}-0.027 \\
(0.017)\end{array}$ & $\begin{array}{l}-0.033 \\
(0.023)\end{array}$ & $\begin{array}{l}-0.039 * * \\
(0.018)\end{array}$ & $\begin{array}{l}-0.034^{* *} \\
(0.015)\end{array}$ & $\begin{array}{l}-0.037 * * \\
(0.017)\end{array}$ & $\begin{array}{l}-0.039^{* *} \\
(0.017)\end{array}$ & $\begin{array}{l}-0.042 * * \\
(0.018)\end{array}$ \\
\hline Window $90 \times$ Outcome change & $\begin{array}{l}0.071^{* *} \\
(0.028) \\
\end{array}$ & $\begin{array}{l}0.071 * * * \\
(0.026)\end{array}$ & $\begin{array}{l}0.067^{* *} \\
(0.028)\end{array}$ & $\begin{array}{l}0.081 * * * \\
(0.026)\end{array}$ & $\begin{array}{l}0.078 * * * \\
(0.026)\end{array}$ & $\begin{array}{l}0.066^{* *} \\
(0.026)\end{array}$ & $\begin{array}{l}0.070 * * * \\
(0.025)\end{array}$ & $\begin{array}{l}0.069^{* *} \\
(0.027)\end{array}$ & $\begin{array}{l}0.077 * * * \\
(0.024)\end{array}$ \\
\hline Sample excluding by-elections in & EC & FS & GP & $\mathrm{KZN}$ & LIM & MP & NW & $\mathrm{NC}$ & WC \\
\hline Initial vote share (at last regular election) & Yes & Yes & Yes & Yes & Yes & Yes & Yes & Yes & Yes \\
\hline Province and year fixed effects & Yes & Yes & Yes & Yes & Yes & Yes & Yes & Yes & Yes \\
\hline Observations & 224 & 243 & 243 & 187 & 239 & 252 & 254 & 251 & 251 \\
\hline R-squared & 0.749 & 0.721 & 0.714 & 0.720 & 0.741 & 0.739 & 0.733 & 0.736 & 0.730 \\
\hline
\end{tabular}

Note: Standard errors clustered by by-election date in parentheses. Province abbreviations: EC = Eastern Cape, FS = Free State, GP = Gauteng Province $\mathrm{KZN}=$ KwaZulu-Natal, LIM = Limpopo, MP = Mpumalanga, NW = North West, NC $=$ Northern Cape, WC $=$ Western Cape.

$* * * \mathrm{p}<0.01, * * \mathrm{p}<0.05, * \mathrm{p}<0.1$ 
Table A11: Excluding by-elections in individual calendar years

\begin{tabular}{|c|c|c|c|c|c|c|c|c|}
\hline & (1) & $(2)$ & (3) & (4) & (5) & $(6)$ & (7) & (8) \\
\hline Outcome change & $\begin{array}{l}-0.013 \\
(0.014)\end{array}$ & $\begin{array}{l}-0.026^{*} \\
(0.014)\end{array}$ & $\begin{array}{l}-0.021 \\
(0.014)\end{array}$ & $\begin{array}{l}-0.016 \\
(0.013)\end{array}$ & $\begin{array}{l}-0.021 \\
(0.015)\end{array}$ & $\begin{array}{l}-0.022 \\
(0.015)\end{array}$ & $\begin{array}{l}-0.021 \\
(0.014)\end{array}$ & $\begin{array}{l}-0.019 \\
(0.014)\end{array}$ \\
\hline Window 90 & $\begin{array}{l}-0.037^{* *} \\
(0.016)\end{array}$ & $\begin{array}{l}-0.049 * * * \\
(0.016)\end{array}$ & $\begin{array}{l}-0.051 * * * \\
(0.017)\end{array}$ & $\begin{array}{l}-0.036 * * \\
(0.016)\end{array}$ & $\begin{array}{l}-0.037^{*} \\
(0.021)\end{array}$ & $\begin{array}{l}-0.035^{* *} \\
(0.017)\end{array}$ & $\begin{array}{l}-0.024 \\
(0.014)\end{array}$ & $\begin{array}{c}-0.033^{*} \\
(0.017)\end{array}$ \\
\hline Window $90 \times$ Outcome change & $\begin{array}{l}0.064 * * \\
(0.024)\end{array}$ & $\begin{array}{l}0.059 * \\
(0.031)\end{array}$ & $\begin{array}{l}0.080 * * \\
(0.034)\end{array}$ & $\begin{array}{l}0.066^{* *} \\
(0.026)\end{array}$ & $\begin{array}{l}0.091 * * * \\
(0.024)\end{array}$ & $\begin{array}{l}0.075 * * * \\
(0.026)\end{array}$ & $\begin{array}{l}0.070 * * * \\
(0.024)\end{array}$ & $\begin{array}{l}0.063 * * \\
(0.024)\end{array}$ \\
\hline Sample excluding calendar year & 2008 & 2009 & 2010 & 2011 & 2012 & 2013 & 2014 & 2015 \\
\hline Initial vote share (at last regular election) & Yes & Yes & Yes & Yes & Yes & Yes & Yes & Yes \\
\hline Province and year fixed effects & Yes & Yes & Yes & Yes & Yes & Yes & Yes & Yes \\
\hline Observations & 235 & 217 & 226 & 258 & 223 & 239 & 240 & 238 \\
\hline R-squared & 0.723 & 0.763 & 0.751 & 0.731 & 0.722 & 0.722 & 0.748 & 0.717 \\
\hline
\end{tabular}

Note: Standard errors clustered by by-election date in parentheses. No observations fall into December 2007, so this year is not dropped. $* * * \mathrm{p}<0.01, * * \mathrm{p}<0.05, * \mathrm{p}<0.1$ 
Table A12: Additional controls

\begin{tabular}{llllll}
\hline & $\mathbf{( 1 )}$ & $\mathbf{( 2 )}$ & $\mathbf{( 3 )}$ & $\mathbf{( 4 )}$ & $\mathbf{( 5 )}$ \\
\hline Outcome change & -0.014 & -0.011 & -0.019 & -0.019 & -0.020 \\
& $(0.014)$ & $(0.015)$ & $(0.014)$ & $(0.013)$ & $(0.013)$ \\
Window 90 & $-0.036^{* *}$ & -0.034 & $-0.059^{* * *}$ & $-0.032^{*}$ & $-0.036^{* *}$ \\
& $(0.016)$ & $(0.021)$ & $(0.020)$ & $(0.016)$ & $(0.016)$ \\
Window 90 x Outcome change & $0.073^{* * *}$ & $0.063^{* *}$ & $0.069^{* * *}$ & $0.077^{* * *}$ & $0.073^{* * *}$ \\
& $(0.025)$ & $(0.024)$ & $(0.026)$ & $(0.024)$ & $(0.025)$ \\
\hline Previous year audit category fixed effects & Yes & No & No & No & No \\
District fixed effects & No & Yes & No & No & No \\
Month of year fixed effects & No & No & Yes & No & No \\
Socio-economic characteristics & No & No & No & Yes & No \\
Days since last regular election & No & No & No & No & Yes \\
\hline Initial vote share (at last regular election) & Yes & Yes & Yes & Yes & Yes \\
Province fixed effects & Yes & No & Yes & Yes & Yes \\
Year fixed effects & Yes & Yes & Yes & Yes & Yes \\
Observations & 268 & 268 & 268 & 267 & 268 \\
R-squared & 0.734 & 0.794 & 0.743 & 0.744 & 0.732 \\
\hline
\end{tabular}

Note: Standard errors clustered by by-election date in parentheses. Municipality characteristics include average household income (logged), population (logged), linguistic fractionalization, proportion of households with radio, proportion of the population with matric or higher education, all from the 2011 Census by StatsSA.

$* * * \mathrm{p}<0.01, * * \mathrm{p}<0.05, * \mathrm{p}<0.1$ 
Table A13: Inverse probability weighting

\begin{tabular}{llll}
\hline & $\mathbf{( 1 )}$ & $\mathbf{( 2 )}$ & $\mathbf{( 3 )}$ \\
\hline Outcome change & -0.020 & -0.014 & -0.013 \\
Window 90 & $(0.013)$ & $(0.014)$ & $(0.014)$ \\
& $-0.036^{* *}$ & -0.023 & -0.020 \\
Window 90 x Outcome change & $(0.014)$ & $(0.018)$ & $(0.017)$ \\
& $0.068^{* * *}$ & $0.066^{* *}$ & $0.063^{* *}$ \\
\hline Initial vote share (at last regular election) & $(0.024)$ & $(0.027)$ & $(0.028)$ \\
Province and year fixed effects & Yes & Yes & Yes \\
Observations & Yes & Yes & Yes \\
R-squared & 267 & 268 & 267 \\
\hline Inverse probability weights from & 0.730 & 0.745 & 0.744 \\
Interacted province and year fixed effects & & & \\
Municipal characteristics & No & Yes & Yes \\
\hline Note: Standard & Yes & No & Yes \\
\hline
\end{tabular}

Note: Standard errors clustered by by-election date in parentheses. Main model (column 4 in Table 1) with stabilized weights based on the predicted probabilities of a series of logistic regression models where the outcome is whether or not each by-election from the primary sample of interest falls into the post-audit report release date window. The municipal characteristics used are $\log$ seats, Flush toilets, and Hospital (as in Table A17).

$* * * \mathrm{p}<0.01, * * \mathrm{p}<0.05, * \mathrm{p}<0.1$ 


\section{Table A14: Context conditions}

\begin{tabular}{|c|c|c|c|c|c|c|c|c|c|c|}
\hline & (1) & $(2)$ & (3) & (4) & (5) & (6) & (7) & (8) & (9) & (10) \\
\hline Window 90 & $\begin{array}{l}-0.043^{* *} \\
(0.018)\end{array}$ & $\begin{array}{l}-0.045 \\
(0.030)\end{array}$ & $\begin{array}{l}0.002 \\
(0.027)\end{array}$ & $\begin{array}{l}-0.034 \\
(0.025)\end{array}$ & $\begin{array}{l}-0.200 \\
(0.144)\end{array}$ & $\begin{array}{l}-0.051 \\
(0.054)\end{array}$ & $\begin{array}{l}-0.124 \\
(0.089)\end{array}$ & $\begin{array}{l}-0.049 \\
(0.032)\end{array}$ & $\begin{array}{l}-0.036 \\
(0.022)\end{array}$ & $\begin{array}{l}-0.010 \\
(0.024)\end{array}$ \\
\hline Window 90 x Outcome change & $\begin{array}{l}0.066^{* * *} \\
(0.025)\end{array}$ & $\begin{array}{l}0.029 \\
(0.036)\end{array}$ & $\begin{array}{l}0.039 \\
(0.042)\end{array}$ & $\begin{array}{l}0.089 * * * \\
(0.031)\end{array}$ & $\begin{array}{l}0.109 \\
(0.189)\end{array}$ & $\begin{array}{l}0.225 * * * \\
(0.078)\end{array}$ & $\begin{array}{l}0.157 \\
(0.136)\end{array}$ & $\begin{array}{l}0.098^{* *} \\
(0.043)\end{array}$ & $\begin{array}{l}0.060^{*} \\
(0.030)\end{array}$ & $\begin{array}{l}0.036 \\
(0.058)\end{array}$ \\
\hline Window $90 \mathrm{x}$ Outcome change $\mathrm{x}$ Attribution barriers & $\begin{array}{l}0.010 \\
(0.053)\end{array}$ & & & & & & & & & \\
\hline Window $90 \times$ Outcome change $\mathrm{x}$ Competitive council & & $\begin{array}{l}0.076^{*} \\
(0.045)\end{array}$ & & & & & & & & \\
\hline Window $90 \times$ Outcome change $\mathrm{x}$ ANC majority & & & $\begin{array}{l}0.044 \\
(0.047)\end{array}$ & & & & & & & \\
\hline Window $90 \times$ Outcome change $x$ Media office & & & & $\begin{array}{l}-0.062 \\
(0.067)\end{array}$ & & & & & & \\
\hline Window $90 \times$ Outcome change $\mathrm{x}$ Households with radio & & & & & $\begin{array}{l}-0.060 \\
(0.297)\end{array}$ & & & & & \\
\hline Window $90 \mathrm{x}$ Outcome change $\mathrm{x}$ Households with internet & & & & & & $\begin{array}{l}-0.567 * * \\
(0.277)\end{array}$ & & & & \\
\hline Window $90 \times$ Outcome change $\mathrm{x}$ Households with TV & & & & & & & $\begin{array}{l}-0.125 \\
(0.199)\end{array}$ & & & \\
\hline Window $90 \times$ Outcome change $\mathrm{x}$ Chief & & & & & & & & $\begin{array}{l}-0.039 \\
(0.050)\end{array}$ & & \\
\hline Window 90 x Outcome change $\mathrm{x}$ Rural & & & & & & & & & $\begin{array}{l}0.027 \\
(0.060)\end{array}$ & \\
\hline Window 90 x Outcome change $\mathrm{x}$ Linguistic fractionalization & & & & & & & & & & $\begin{array}{l}0.017 \\
(0.024) \\
\end{array}$ \\
\hline Initial vote share (at last regular election) & Yes & Yes & Yes & Yes & Yes & Yes & Yes & Yes & Yes & Yes \\
\hline Province and year fixed effects & Yes & Yes & Yes & Yes & Yes & Yes & Yes & Yes & Yes & Yes \\
\hline Observations & 268 & 267 & 268 & 268 & 267 & 267 & 267 & 268 & 267 & 267 \\
\hline R-squared & 0.734 & 0.737 & 0.746 & 0.733 & 0.735 & 0.736 & 0.735 & 0.739 & 0.734 & 0.735 \\
\hline
\end{tabular}

Note: Standard errors clustered by by-election date in parentheses. In this table, we report results where our main model from column 4 of Table 1 is augmented with a three-way interaction with the relevant context variable indicated above. A full set of constituent interactions is included in each model, but we omit these here for presentational purposes. The replication package includes the code with which to obtain the full sets of coefficients.

$* * * \mathrm{p}<0.01, * * \mathrm{p}<0.05, * \mathrm{p}<0.1$ 
Table A15: Audit outcome in levels

\begin{tabular}{|c|c|c|c|c|c|}
\hline & (1) & (2) & (3) & (4) & (5) \\
\hline Outcome in levels & $\begin{array}{l}-0.035^{*} \\
(0.019)\end{array}$ & $\begin{array}{l}-0.022 \\
(0.022)\end{array}$ & $\begin{array}{l}0.018^{*} \\
(0.010)\end{array}$ & $\begin{array}{l}0.007 \\
(0.015)\end{array}$ & \\
\hline Window 90 & $\begin{array}{l}0.018 \\
(0.029)\end{array}$ & $\begin{array}{l}0.024 \\
(0.027)\end{array}$ & $\begin{array}{l}-0.019 \\
(0.014)\end{array}$ & $\begin{array}{l}-0.023 \\
(0.016)\end{array}$ & $\begin{array}{l}0.017 \\
(0.045)\end{array}$ \\
\hline Window 90 x Outcome in levels & & $\begin{array}{l}-0.066^{*} \\
(0.034)\end{array}$ & $\begin{array}{l}-0.021 \\
(0.019)\end{array}$ & $\begin{array}{l}-0.014 \\
(0.019)\end{array}$ & \\
\hline Good audit & & & & & $\begin{array}{l}0.024 \\
(0.027)\end{array}$ \\
\hline Window 90 x Good audit & & & & & $\begin{array}{l}-0.065 \\
(0.063)\end{array}$ \\
\hline Bad audit & & & & & $\begin{array}{l}0.011 \\
(0.029)\end{array}$ \\
\hline Window $90 \times$ Bad audit & & & & & $\begin{array}{l}-0.040 \\
(0.055)\end{array}$ \\
\hline Constant & $\begin{array}{l}0.653 * * * \\
(0.016)\end{array}$ & $\begin{array}{l}0.653 * * * \\
(0.016)\end{array}$ & $\begin{array}{l}0.058^{* *} \\
(0.029)\end{array}$ & $\begin{array}{l}0.104 * * \\
(0.040) \\
\end{array}$ & $\begin{array}{l}0.087^{*} \\
(0.049) \\
\end{array}$ \\
\hline Window $90 \mid$ Outcome in levels $=1$ & & $\begin{array}{l}-0.042 \\
0.047\end{array}$ & $\begin{array}{l}-0.041 * \\
(0.024)\end{array}$ & $\begin{array}{l}-0.037 \\
(0.026)\end{array}$ & \\
\hline Window $90 \mid$ Outcome in levels $=-1$ & & $\begin{array}{l}0.089 * * \\
(0.039)\end{array}$ & $\begin{array}{l}0.002 \\
(0.022)\end{array}$ & $\begin{array}{l}-0.009 \\
(0.024)\end{array}$ & \\
\hline Window $90 \mid$ Good audit = 1 & & & & & $\begin{array}{l}-0.048 \\
(0.031)\end{array}$ \\
\hline Window $90 \mid$ Bad audit $=1$ & & & & & $\begin{array}{l}-0.023 \\
(0.026)\end{array}$ \\
\hline Initial vote share (at last regular election) & No & No & Yes & Yes & Yes \\
\hline Province and year fixed effects & No & No & No & Yes & Yes \\
\hline Observations & 269 & 269 & 269 & 269 & 269 \\
\hline R-squared & 0.018 & 0.027 & 0.705 & 0.728 & 0.729 \\
\hline
\end{tabular}

Note: Standard errors clustered by by-election date in parentheses.

$* * * \mathrm{p}<0.01, * * \mathrm{p}<0.05, * \mathrm{p}<0.1$ 
Table A16: Turnout as dependent variable

\begin{tabular}{|c|c|c|c|c|c|}
\hline & (1) & (2) & (3) & (4) & (5) \\
\hline Outcome change & $\begin{array}{l}0.002 \\
(0.013)\end{array}$ & $\begin{array}{l}0.013 \\
(0.013)\end{array}$ & $\begin{array}{l}0.011 \\
(0.010)\end{array}$ & $\begin{array}{l}0.008 \\
(0.010)\end{array}$ & \\
\hline Window 90 & $\begin{array}{l}0.016 \\
(0.020)\end{array}$ & $\begin{array}{l}0.027 \\
(0.022)\end{array}$ & $\begin{array}{l}0.004 \\
(0.014)\end{array}$ & $\begin{array}{l}0.004 \\
(0.012)\end{array}$ & $\begin{array}{l}0.009 \\
(0.015)\end{array}$ \\
\hline Window $90 \times$ Outcome change & & $\begin{array}{l}-0.058 \\
(0.036)\end{array}$ & $\begin{array}{l}-0.044^{*} \\
(0.022)\end{array}$ & $\begin{array}{l}-0.033 \\
(0.023)\end{array}$ & \\
\hline Better & & & & & $\begin{array}{l}0.016 \\
(0.015)\end{array}$ \\
\hline Window 90 x Better & & & & & $\begin{array}{l}-0.043 \\
(0.034)\end{array}$ \\
\hline Worse & & & & & $\begin{array}{l}0.004 \\
(0.017)\end{array}$ \\
\hline Window $90 \times$ Worse & & & & & $\begin{array}{l}0.017 \\
(0.032)\end{array}$ \\
\hline Constant & $\begin{array}{l}0.387 * * * \\
(0.008)\end{array}$ & $\begin{array}{l}0.386^{* * *} * \\
(0.008)\end{array}$ & $\begin{array}{l}-0.027 \\
(0.049)\end{array}$ & $\begin{array}{l}0.030 \\
(0.062)\end{array}$ & $\begin{array}{l}0.028 \\
(0.063) \\
\end{array}$ \\
\hline Window $90 \mid$ Outcome change $=1$ & & $\begin{array}{l}-0.031 \\
(0.037)\end{array}$ & $\begin{array}{l}-0.040^{*} \\
(0.022)\end{array}$ & $\begin{array}{l}-0.029 \\
(0.027)\end{array}$ & \\
\hline Window $90 \mid$ Outcome change $=-1$ & & $\begin{array}{l}0.085^{*} \\
(0.047)\end{array}$ & $\begin{array}{l}0.048 \\
(0.030)\end{array}$ & $\begin{array}{l}0.037 \\
(0.025)\end{array}$ & \\
\hline Window $90 \mid$ Better $=1$ & & & & & $\begin{array}{l}-0.035 \\
(0.032)\end{array}$ \\
\hline Window $90 \mid$ Worse $=1$ & & & & & $\begin{array}{l}0.026 \\
(0.028)\end{array}$ \\
\hline Initial turnout (at last regular election) & No & No & Yes & Yes & Yes \\
\hline Province and year fixed effects & No & No & No & Yes & Yes \\
\hline Observations & 268 & 268 & 268 & 268 & 268 \\
\hline R-squared & 0.003 & 0.016 & 0.406 & 0.554 & 0.556 \\
\hline
\end{tabular}

Note: Standard errors clustered by by-election date in parentheses

$* * * \mathrm{p}<0.01, * * \mathrm{p}<0.05, * \mathrm{p}<0.1$ 
Table A17: Frequency of by-elections triggered by death across municipalities

\begin{tabular}{llllll}
\hline & $\mathbf{( 1 )}$ & $\mathbf{( 2 )}$ & $\mathbf{( 3 )}$ & $\mathbf{( 4 )}$ & $\mathbf{( 5 )}$ \\
\hline Log seats & $0.907^{* * *}$ & $1.003^{* * *}$ & $0.977^{* * *}$ & $0.931^{* * *}$ & $1.881^{* * *}$ \\
& $(0.093)$ & $(0.103)$ & $(0.105)$ & $(0.103)$ & $(0.367)$ \\
Flush toilets & 0.159 & 0.345 & & 0.260 & -0.668 \\
& $(0.190)$ & $(0.246)$ & & $(0.251)$ & $(0.806)$ \\
Piped water & & & & \\
& & & & $-1.250^{*}$ \\
Hospital & $-0.348^{* *}$ & $-0.475^{* * *}$ & $-0.405^{* *}$ & & $(0.662)$ \\
& $(0.174)$ & $(0.177)$ & $(0.177)$ & & \\
Larger hospital & & & & $-0.376^{*}$ & $(0.211)$ \\
& & & & Quasi-Poisson & Logistic \\
\hline $\begin{array}{l}\text { Model } \\
\text { Province fixed effects }\end{array}$ & Quasi-Poisson & Quasi-Poisson & Quasi-Poisson & Yes \\
Observations & 234 & Yes & Yes & 234 & 234 \\
\hline *** & 234 & 234 & & \\
\hline
\end{tabular}

${ }^{* * *} \mathrm{p}<0.01,{ }^{* *} \mathrm{p}<0.05,{ }^{*} \mathrm{p}<0.1$

Note: Cross-sectional models of the total frequency of by-elections triggered by deaths in office for each municipality over the period 2007-2015. In Model 5 only, the outcome is dichotomous for the incidence of any byelections triggered by death. Log seats is the natural log of the total number of council seats. Flush toilets and Piped water are the proportion of municipal population reporting access to each (in their home) in the 2011 Census.

Hospital is an indicator for the presence of a provincial, central, or regional hospital in the municipality, based on the official categories of public hospitals published by the Department of Health in Government Gazette No. 35101 (March 2, 2012). Larger hospital is an indicator for a provincial or central hospital only. 
Table A18: Different time windows (survey data)

\begin{tabular}{|c|c|c|c|c|}
\hline & (1) & (2) & (3) & (4) \\
\hline Outcome change & $\begin{array}{l}0.066 \\
(0.049)\end{array}$ & $\begin{array}{l}0.043 \\
(0.050)\end{array}$ & $\begin{array}{l}0.017 \\
(0.053)\end{array}$ & $\begin{array}{l}0.020 \\
(0.053)\end{array}$ \\
\hline Post-release (1-week window) & $\begin{array}{l}0.539^{*} \\
(0.286)\end{array}$ & & & \\
\hline Post-release (1-week window) x Outcome change & $\begin{array}{l}0.506 \\
(0.375)\end{array}$ & & & \\
\hline Post-release (2-week window) & & $\begin{array}{l}0.025 \\
(0.090)\end{array}$ & & \\
\hline Post-release (2-week window) x Outcome change & & $\begin{array}{l}0.257 * \\
(0.143)\end{array}$ & & \\
\hline Post-release (3-week window) & & & $\begin{array}{l}0.021 \\
(0.082)\end{array}$ & \\
\hline Post-release (3-week window) x Outcome change & & & $\begin{array}{l}0.197 * * \\
(0.093)\end{array}$ & \\
\hline Post-release (4-week window) & & & & $\begin{array}{l}0.037 \\
(0.119)\end{array}$ \\
\hline Post-release (4-week window) x Outcome change & & & & $\begin{array}{l}0.175^{* *} * \\
(0.086)\end{array}$ \\
\hline Post-release (x-week window) $\mid$ Outcome change $=1$ & $\begin{array}{l}1.044 * \\
(0.618)\end{array}$ & $\begin{array}{l}0.282 \\
(0.202)\end{array}$ & $\begin{array}{l}0.218 \\
(0.140)\end{array}$ & $\begin{array}{l}0.211 \\
(0.157)\end{array}$ \\
\hline Post-release ( $\mathrm{x}$-week window) $\mid$ Outcome change $=-1$ & $\begin{array}{l}0.033 \\
(0.251)\end{array}$ & $\begin{array}{l}-0.232 * \\
(0.127) \\
\end{array}$ & $\begin{array}{l}-0.177^{*} \\
(0.105) \\
\end{array}$ & $\begin{array}{l}-0.138 \\
(0.136) \\
\end{array}$ \\
\hline Observations & 3,402 & 3,402 & 3,402 & 3,402 \\
\hline R-squared & 0.064 & 0.065 & 0.066 & 0.065 \\
\hline
\end{tabular}

Note: Standard errors in parentheses. Linear models of Mayor approval. All models also include province fixed

effects and controls for the running variable (cubic); indicator for metropolitan, urban, or rural; age; education; income (with a separate dummy variable for no response); unemployment; gender; race. Sample restricted to respondents in municipalities without mayoral changes between the 2016 local elections and the period covered by the survey in 2018 (excluding 26 such municipalities).

$* * * \mathrm{p}<0.01, * * \mathrm{p}<0.05, * \mathrm{p}<0.1$ 
Table A19: Respondents who have heard of municipal audits (survey data)

\begin{tabular}{lllll}
\hline & $\mathbf{( 1 )}$ & $\mathbf{( 2 )}$ & $\mathbf{( 3 )}$ & $\mathbf{( 4 )}$ \\
\hline Post-release & $0.129^{* *}$ & $0.135^{* *}$ & $0.051^{*}$ & $0.595^{* *}$ \\
& $(0.061)$ & $(0.065)$ & $(0.029)$ & $(0.274)$ \\
\hline Model & Linear & Linear & Linear & Logistic \\
Fixed Effects & Province & Municipality & Province & Province \\
Running Variable & Nonlinear & Nonlinear & Linear & Nonlinear \\
Observations & 5,200 & 5,200 & 5,200 & 5,200 \\
R-squared & 0.052 & 0.126 & 0.052 & \\
\hline
\end{tabular}

Note: Standard errors in parentheses. All models also include controls for the running variable (cubic or linear); indicator for metropolitan, urban, or rural; age; education; income (with a separate dummy variable for no response); unemployment; gender; race.

$* * * \mathrm{p}<0.01, * * \mathrm{p}<0.05, * \mathrm{p}<0.1$ 
Table A20: Respondents who say corruption and financial mismanagement information is very important in voting (survey data)

\begin{tabular}{lllll}
\hline & $(\mathbf{1})$ & $\mathbf{( 2 )}$ & $\mathbf{( 3 )}$ & $\mathbf{( 4 )}$ \\
\hline Post-release & -0.020 & $-0.104^{*}$ & -0.001 & -0.147 \\
& $(0.061)$ & $(0.062)$ & $(0.030)$ & $(0.303)$ \\
\hline Model & Linear & Linear & Linear & Logistic \\
Fixed Effects & Province & Municipality & Province & Province \\
Running Variable & Nonlinear & Nonlinear & Linear & Nonlinear \\
Observations & 5,069 & 5,069 & 5,069 & 5,069 \\
R-squared & 0.044 & 0.140 & 0.043 & \\
\hline
\end{tabular}

Note: Standard errors in parentheses. All models also include controls for the running variable (cubic or

linear); indicator for metropolitan, urban, or rural; age; education; income (with a separate dummy variable for no response); unemployment; gender; race.

$* * * \mathrm{p}<0.01, * * \mathrm{p}<0.05, * \mathrm{p}<0.1$ 
Figure A1: Media attention to municipal audits spikes after the release of the Auditor-General's report (overlay version)

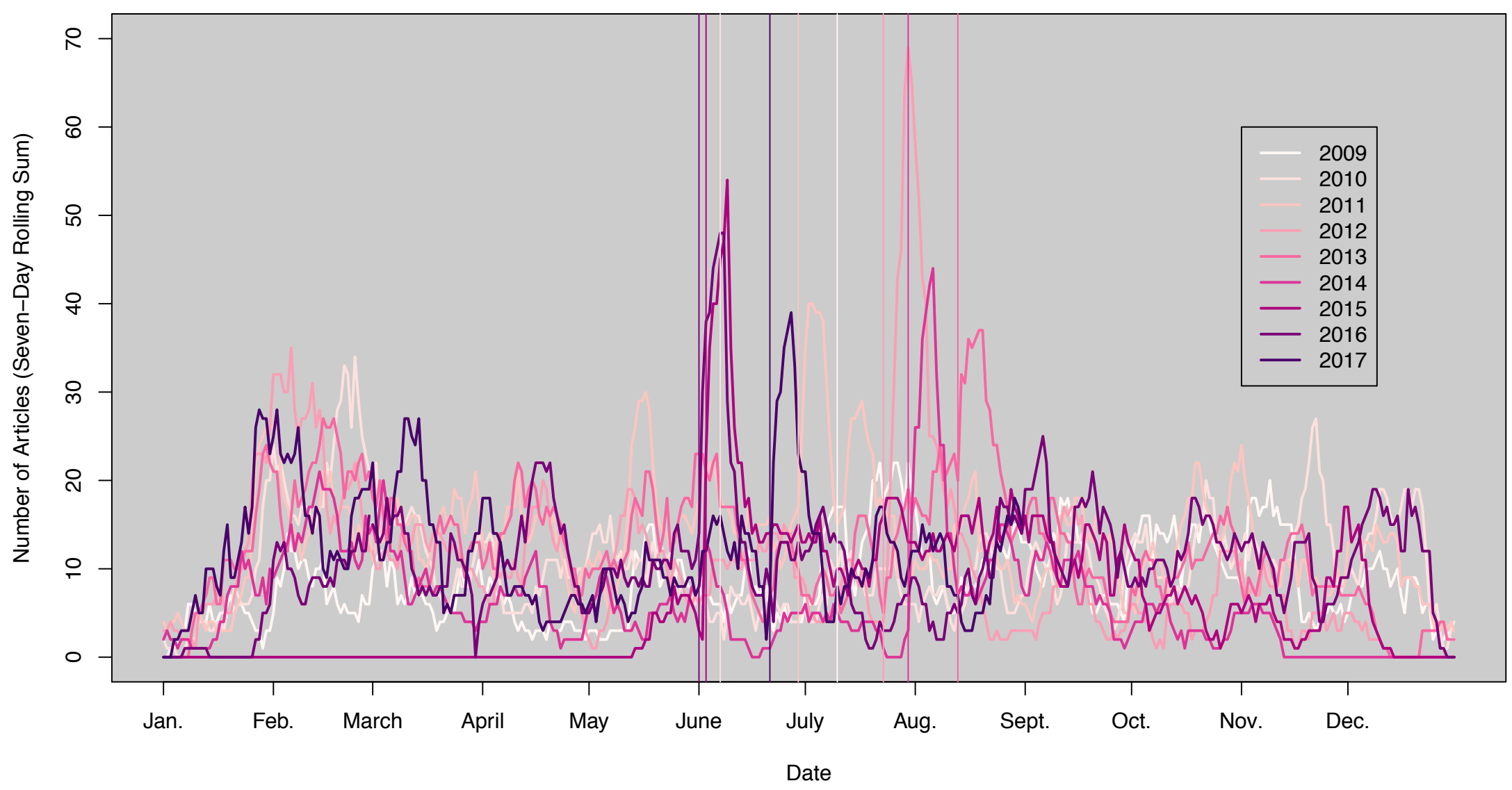

Note: The vertical lines indicate the release date of the Auditor-General's summary report on municipal audits. The number of articles count was calculated as the seven-day rolling sum of newspaper articles extracted from Sabinet's SA Media database over the period January 29-31, 2018, using the following search query: (municipal OR municipality OR "local government") AND (audit OR "auditor general" OR "irregular expenditure" OR "unauthorised expenditure" OR "fruitless and wasteful expenditure"). At the time of data extraction, the database covered 38 mainstream South African media publications with national or regional distribution. A change in Sabinet's collection procedure resulted in a gap in coverage from late 2014 to early 2015, visible as the flat line over that period. 
Figure A2: Eyewitness News municipal audits portal

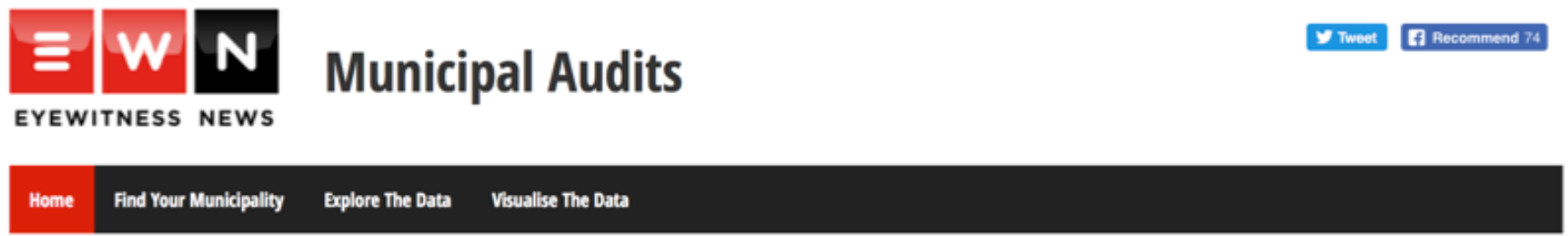

The EWN Municipal Audit Portal keeps track of unauthorised, irregular, fruitless and wasteful expenditure made by municipalities throughout South Africa.

\section{Latest News}

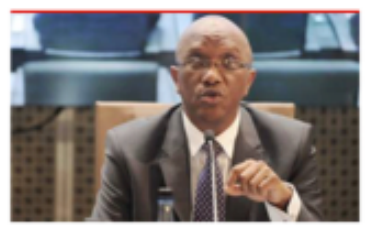

AG concerned by water

management in Western Cape

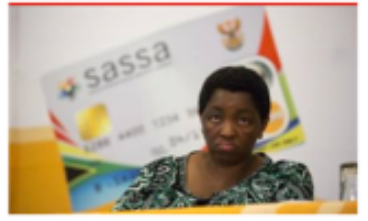

'Irregular expenditure by

Government robs social grant

recipients of R233/month

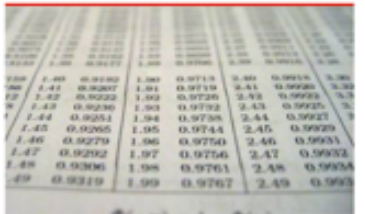

WC govt seeks to improve on municipal audit results

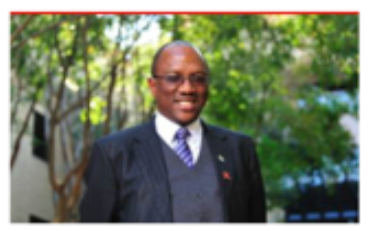

GP municipalities obtain

unqualified audit opinions on financial statements

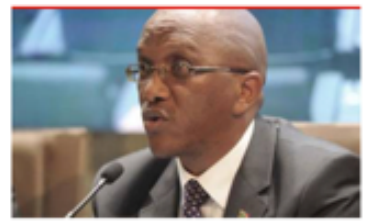

Makwetu calls for serious consequences for audit transgressions

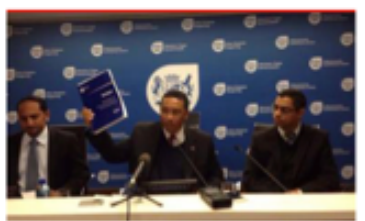

Western Cape govt receives $100 \%$ clean audit
- Find your municipality and find out exactly how resources were spent

Explore the data in more detail here

Visualise the data on the easy-to-use expenditure slider

\section{What is irregular expenditure?}

Irregular expenditure is expenditure that was not incurred in the manner prescribed by legislation. Such expenditure does not necessarily mean that money had been wasted or that fraud had been committed. However it is an indicator of irregularities in prer, it an indicator of procurement of goods and services and a measure of a municipality's ability to comply with legislation relating to expenditure and procurement management.

Source: Screenshot of Eyewitness News municipal audit portal, http://ewn.co.za/tools/municipal-audits/ (accessed April 17, 2018). 
Figure A3: Example of ANC-run municipality advertising audit outcomes

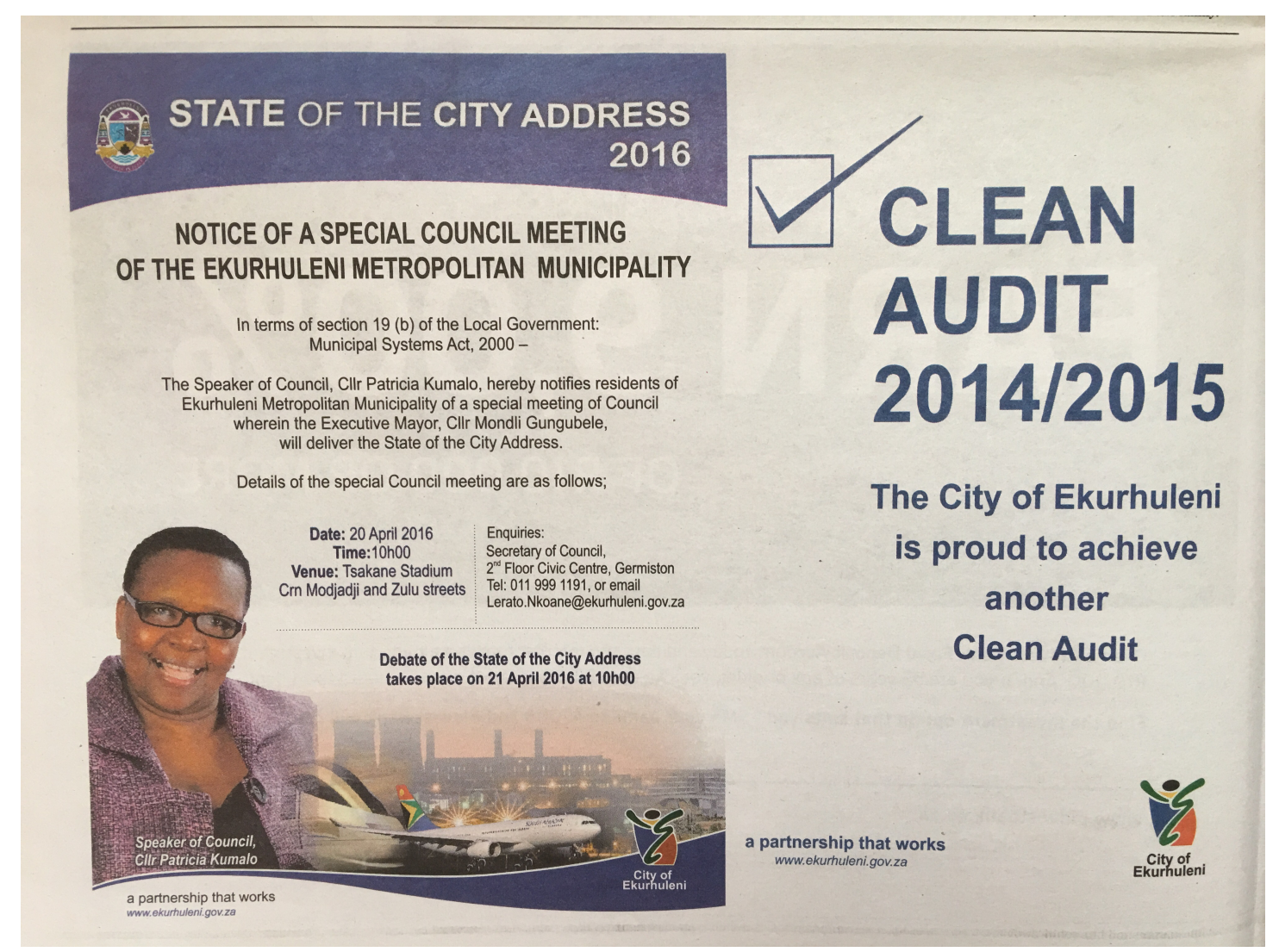

Source: Mail \& Guardian, print edition, April 8-14, 2016, page 14. 
Figure A4: Example of DA advertising municipal audit outcomes

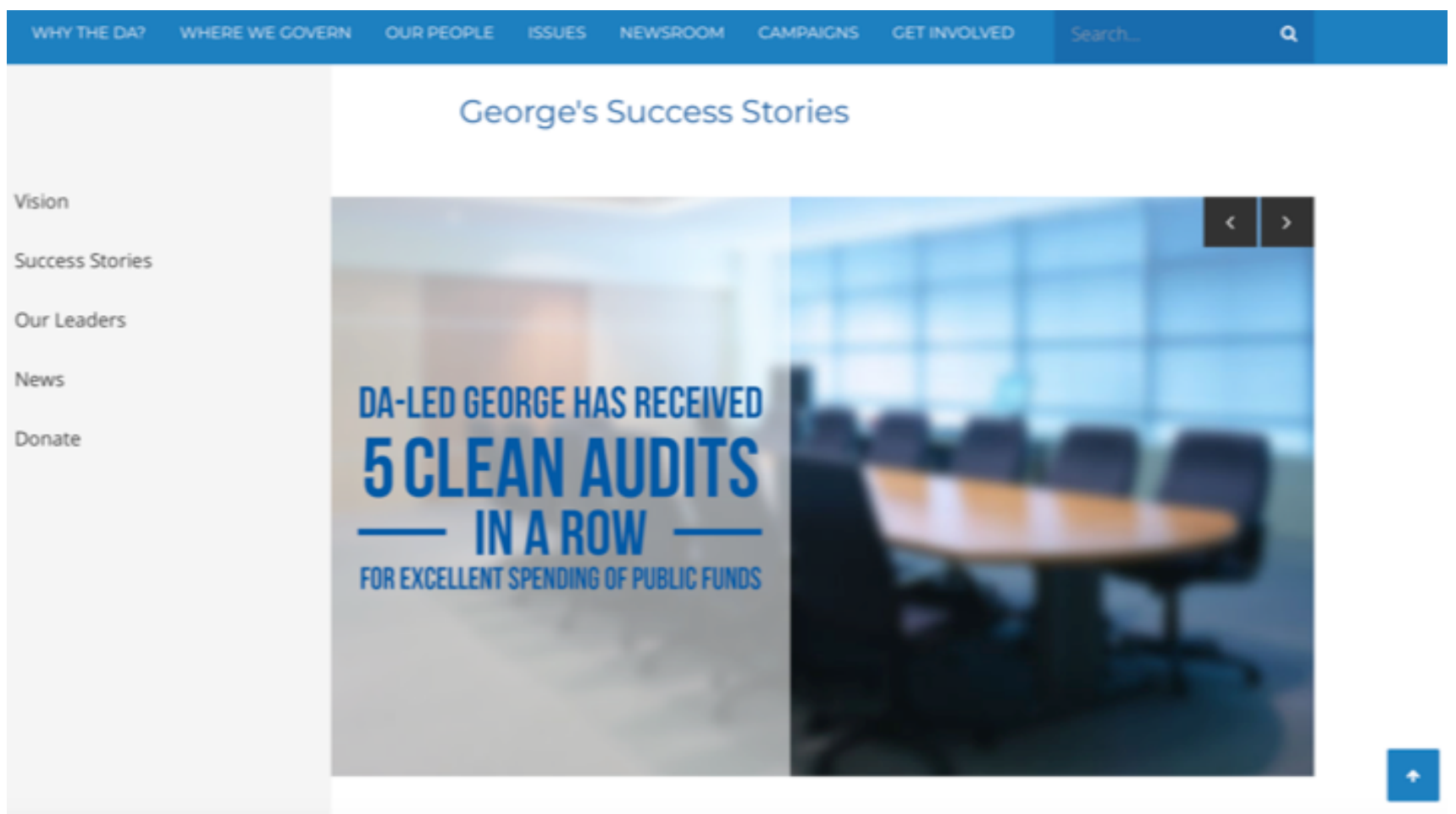

Source: Screenshot of Democratic Alliance website, https://www.da.org.za/da-governed-municipalities/george/ (accessed April 17, 2018). 
Figure A5: Treatment assignment of by-elections

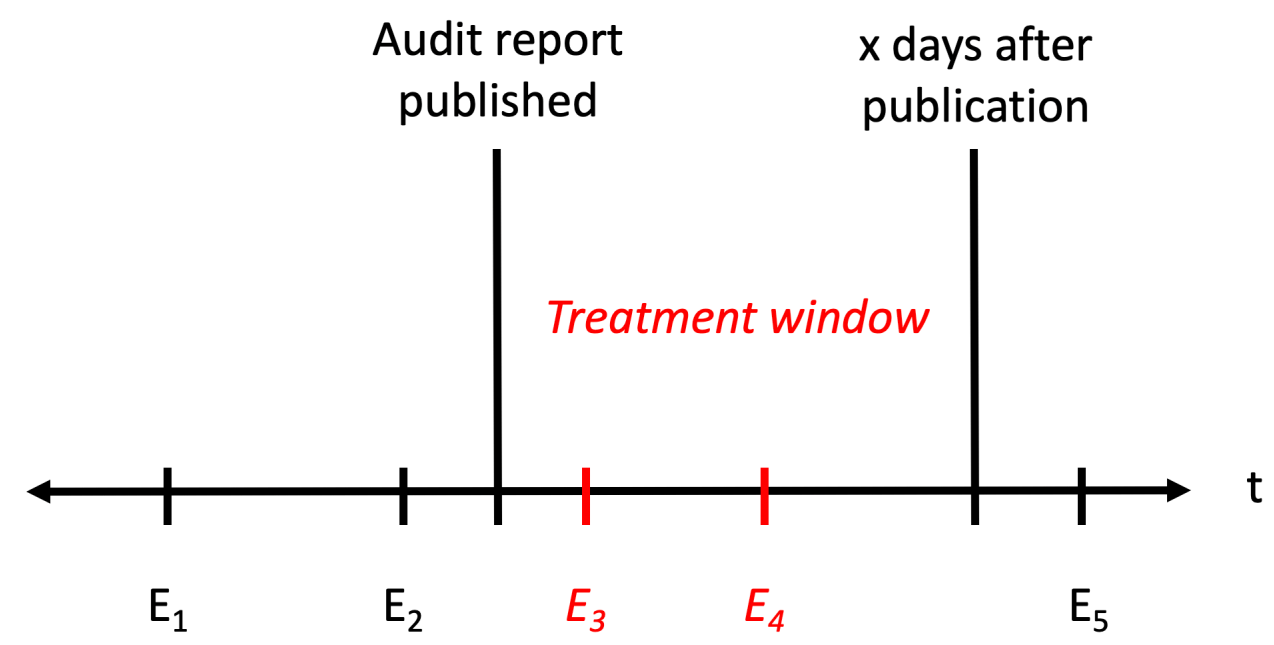

Note: By-elections $E$ are triggered by the death of an incumbent ward councilor and occur at time $t$ throughout the year. Here, the third and fourth by-elections are "treated" as they fall into the period of $x$ days following the release of the Auditor-General's municipal audit report. 
Figure A6: McCrary sorting tests

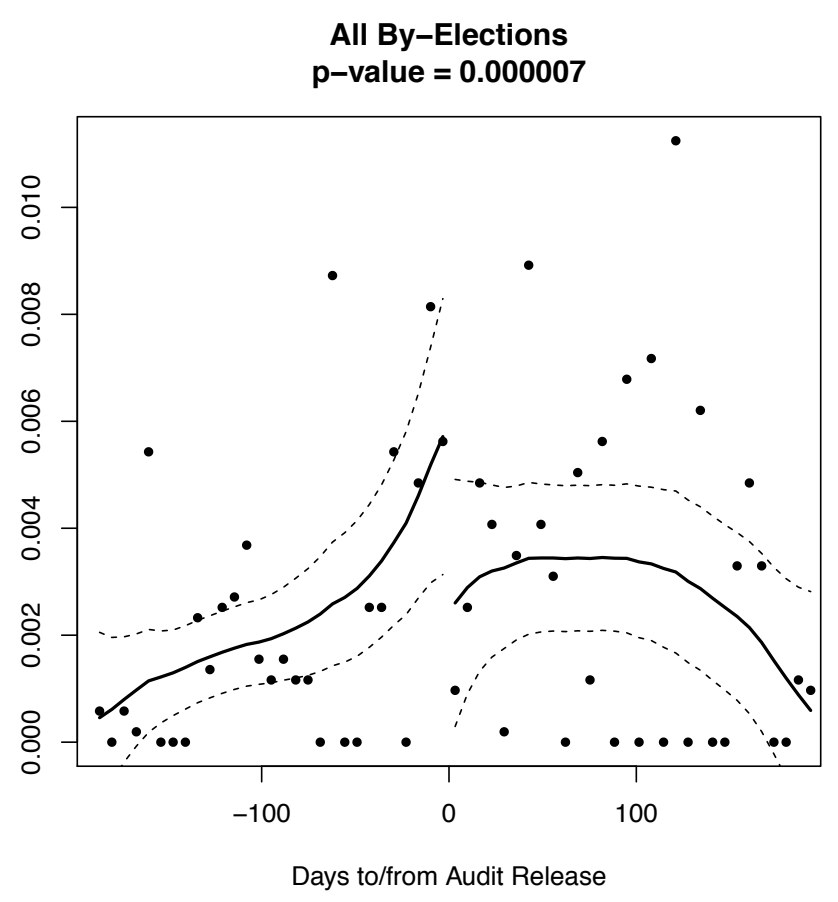

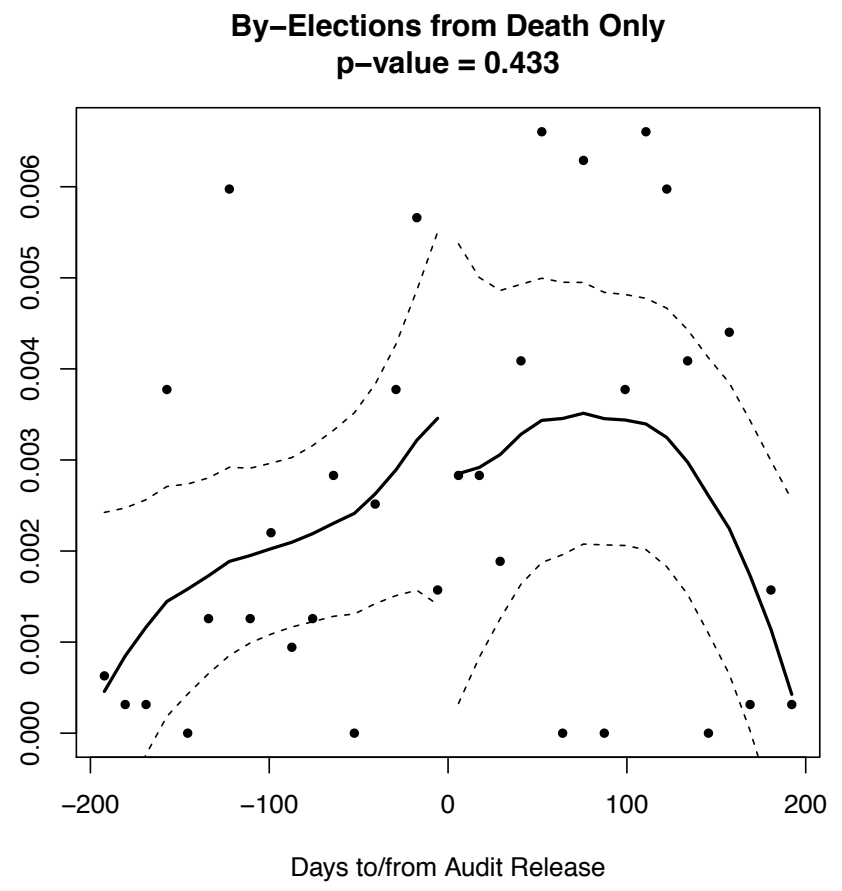


Figure A7: Overview of municipal audit outcomes for financial years 2006-7 to 2013-14 (line graph version)

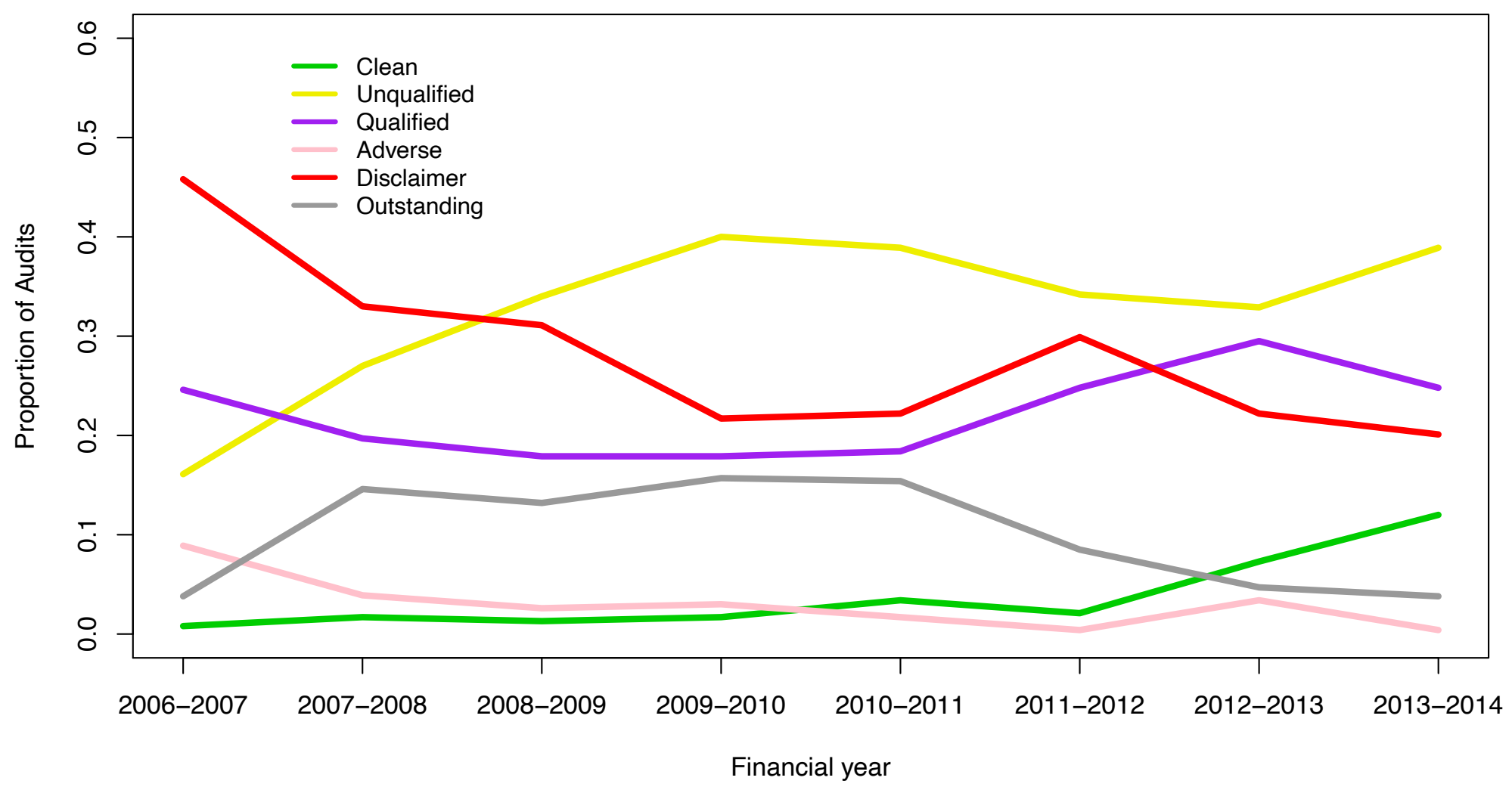

Source: See Table A2. 


\section{Figure A8: Use of color-coding and arrows in audit reports}

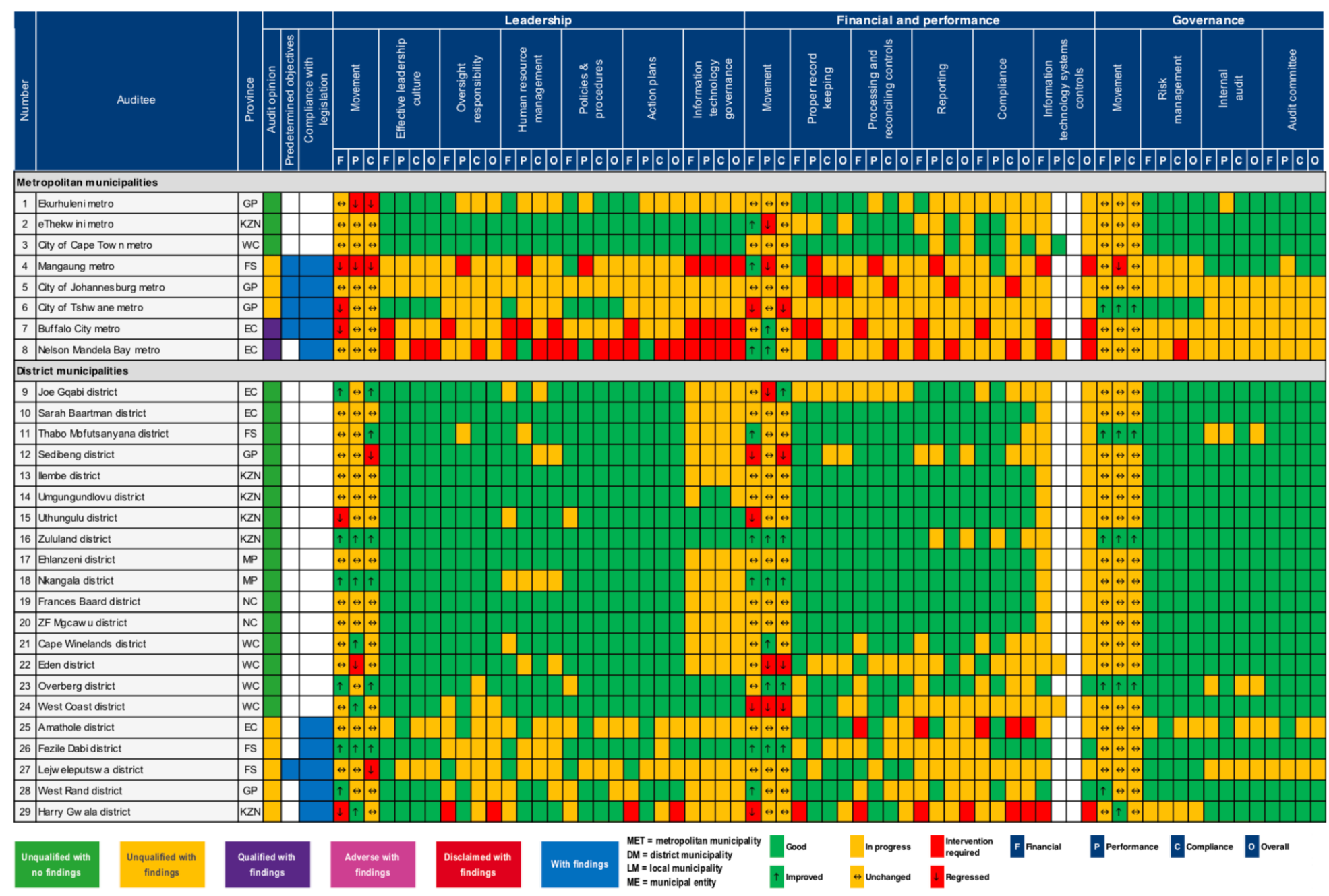

Source: Auditor-General of South Africa. 2016. Consolidated General Report on the Audit Outcomes of Local Government 2014-15. Pretoria, Auditor-General of South Africa. Extract from Annexure 3, page 133. 
Figure A9: Graph of main regression results

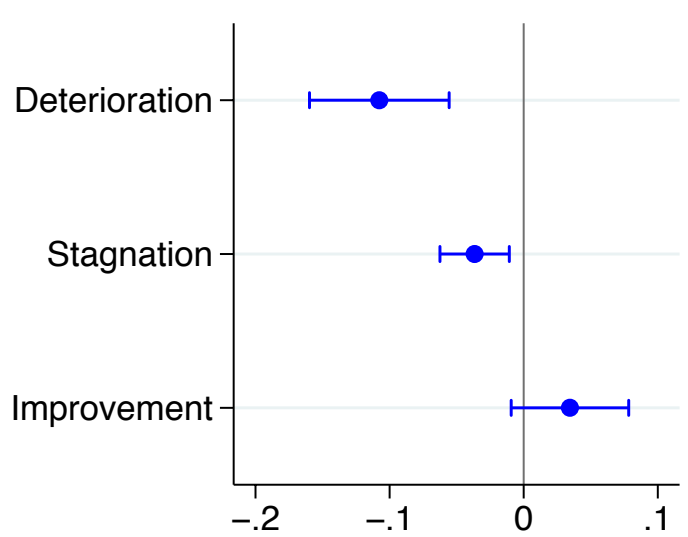

(a) Trichotomous Measure

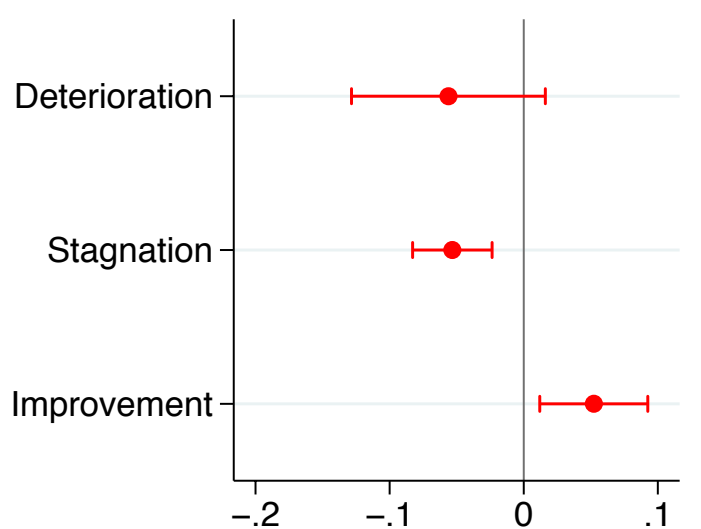

(b) Separate Indicators

Marginal Effect of Audit Information on the Relevant Party's Vote Share

Note: Based on the results in columns 4 (left) and 5 (right) of Table 1 and with $90 \%$ confidence intervals. 


\section{Data appendix}

\section{(i) By-elections dataset}

ANC majority: Equal to 1 where the ANC holds a majority of seats on the council. Source: Original election results from Electoral Commission of South Africa (IEC), http://www.elections.org.za/content/Elections/Municipal-elections-results/; updated with subsequent by-election results and floor-crossings.

Attribution barriers: Equal to 1 if any one or more of the following conditions hold, 0 otherwise: (i) the political party of the mayor at the time of the by-election is different from the political party of the mayor at end of relevant financial year, (ii) mayors from more than one political party were in office during the relevant financial year, and (iii) no single party had a majority on the council at any point during relevant financial year, e.g., several parties or independents formed a coalition. Source: Own data collection.

Bad audit: Equal to 1 if the Auditor-General reports an adverse opinion, disclaimer, or outstanding audit in the relevant annual report on municipal audits, 0 otherwise. Source: Annexure 1 of the Consolidated General Reports on the Audit Outcomes of Local Government for the 2006-7 to 2013-14 financial years, https:/www.agsa.co.za/Reporting/MFMAReports.aspx.

Better: Equal to 1 if a municipality had a year-on-year improvement in audit outcome, 0 otherwise. Source: Outcome change.

Biggest party seat share (on council): The seat share of the largest party on the council. Source: Original election results from Electoral Commission of South Africa (IEC), http://www.elections.org.za/content/Elections/Municipal-elections-results/; updated with subsequent by-election results and floor-crossings.

Chief: Equal to 1 if any ward of a municipality falls within the territory of a former Bantustan created under the apartheid regime, 0 otherwise. Source: De Kadt and Larreguy (2018).

Competitive council: Equal to 1 where the seat difference between the first and second-largest parties on the council is below the median value (22). Seat difference is measured in absolute not relative terms, as - for instance - a ten percent seat difference would be indicate far more competitiveness on a smaller council than on a larger one. Source: Original election results from Electoral Commission of South Africa (IEC), http://www.elections.org.za/content/Elections/Municipal-elections-results/; updated with subsequent by-election results and floor-crossings.

Contested: Equal to 1 if more than one party participated in a by-election, 0 otherwise. 
Days since last regular election: At the time of a by-election, the number of days that have passed since the last countrywide regular municipal election (either March 1, 2006, or May 18, 2011).

Days since last release $(\log )$ : The log of the number of days since the last Auditor General's municipal audit report release date, with the day of the release set to one. Observations before the first release date used in our study (July 10, 2009) are coded as missing. Source: Appendix Table A2.

Good audit: Equal to 1 if the Auditor-General reports a clean or unqualified audit outcome in the relevant annual report on municipal audits, 0 otherwise. Source: Annexure 1 of the Consolidated General Reports on the Audit Outcomes of Local Government for the 2006-7 to 2013-14 financial years, https:/www.agsa.co.za/Reporting/MFMAReports.aspx

Households with internet: Proportion of municipal households with access to the internet according to the 2011 Census. Source: StatsSA.

Households with radio: Proportion of municipal households with a radio according to the 2011 Census. Source: StatsSA.

Households with television: Proportion of municipal households with a television according to the 2011 Census. Source: StatsSA.

Initial turnout: Ratio of the number of votes cast to the number of registered voters in the last regular municipal election. Source: Electoral Commission of South Africa (IEC), http://www.elections.org.za/content/Elections/Municipal-elections-results/.

Initial vote share: Vote share in the last regular municipal election of the party of the municipality's mayor at the end of the financial year to which the relevant audit outcome applies. For example, for a ward by-election in May of 2013, this is the vote share in the 2011 municipal election of the party of the mayor in office at the end of June 2012. Source: Electoral Commission of South Africa (IEC), http://www.elections.org.za/content/Elections/Municipal-elections-results/.

Linguistic fractionalization: Equal to 1 divided by the Herfindahl Index computed with language shares from the 2011 Census. Source: StatsSA.

Media office: Equal to 1 where the municipality hosts the office of a community, regional, or national newspaper, magazine, or radio station. Source: South Africa GCIS Media Directory, https:/www.gcis.gov.za/sites/default/files/docs/services/media.pdf. 
Outcome change: Equal to 1 if the Auditor-General reports a year-on-year improvement in audit outcome in the relevant annual report on municipal audits, 0 for no year-on-year change, and -1 for a year-on-year deterioration. An improvement (deterioration) is defined as a move up (down) the list of official audit categories in Appendix Table A1. We use only the contemporaneous audit outcomes as reported by the auditor general, not including subsequent updates for instance in the case of outstanding audits, so as to capture the information available to the public at that time. Following the statutory timeline that envisages the finalization of audits five months after the end of the relevant financial year, we update this variable to the latest results for the previous financial year on 1 December of each calendar year. For South African municipalities, the financial year runs from 1 July to 30 June of the following calendar year. Source: Annexure 1 of the Consolidated General Reports on the Audit Outcomes of Local Government for the 2006-7 to 2013-14 financial years, https://www.agsa.co.za/Reporting/MFMAReports.aspx.

Outcome in levels: Equal to 1 if the Auditor-General reports a clean or unqualified audit outcome in the relevant annual report on municipal audits, 0 for a qualified audit outcome, and -1 for an adverse opinion, disclaimer, or outstanding audit. Source: Annexure 1 of the Consolidated General Reports on the Audit Outcomes of Local Government for the 2006-7 to 2013-14 financial years, https://www.agsa.co.za/Reporting/MFMAReports.aspx.

Rural: Equal to 1 if a municipality is classified as "mainly rural with communal tenure and with, at most, one or two small towns in their area" (category B4 municipality) according to the government's Municipal Infrastructure Investment Framework (MIIF), 0 otherwise. Source: Municipal Demarcation Board, State Municipal Capacity Assessment 2010/2011: National Trends in Municipal Capacity, September 30, 2012: Annexure A.

Turnout: Ratio of the number of votes cast to the number of registered voters in the ward by-election. Source: Electoral Commission of South Africa (IEC), http://www.elections.org.za/content/Elections/Municipal-by-elections-results/.

Vote share: Vote share in the ward by-election of the party of the municipality's mayor at the end of the financial year to which the relevant audit outcome applies. For example, for a ward by-election in May of 2013, this is the vote share of the party of the mayor in office at the end of June 2012 (just prior to the start of the new financial year on July 1, 2012). Source: Electoral Commission of South Africa (IEC), http://www.elections.org.za/content/Elections/Municipal-by-elections-results/.

Window 30/60/90/120: Indicator of whether a by-election is held within 30/60/90/120 days of the timely release of an AuditorGeneral's annual report on municipal audit outcomes as reported in Appendix Table A2. The release of the 2006-7 report is not deemed timely, as it occurred almost two years after the end of the relevant financial year. Source: Release dates were provided by the Auditor-General of South Africa (AGSA) and verified against press reports extracted from Sabinet's SA Media Database as well as official AGSA press releases, https://www.agsa.co.za/MediaRoom/Mediareleases.aspx. 
Worse: Equal to 1 if a municipality had a year-on-year deterioration in audit outcome, 0 otherwise. Source: Outcome change.

(ii) Survey dataset

Age: Age reported in years.

Corruption very important: Equal to 1 for individuals who claim information about corruption and financial mismanagement in their municipality is VERY important in deciding which political party they will vote for in a municipal election or by-elections; 0 otherwise.

Date: Number of days elapsed from the first day in the sample.

Education: Reported education coded into an ordinal variable with 11 values: 0 for "No school," 1 for "Some primary school," 2 for "Primary school completed," 3 for "Some high school," 4 for "High school completed," 5 for "Some college," 6 for "College completed," 7 for "Some university," 8 for "Technicon diploma / degree," 9 for "University degree / diploma," and 10 for "Postgraduate degree."

Female: Equal to 1 for individuals whose reported gender was "Female," 0 otherwise.

Heard of audits: Equal to 1 for individuals who claim they have heard, seen, or read about EITHER the audit results of the municipal audit carried out for their local municipality, OR reports of unauthorized, irregular, or fruitless and wasteful spending by their municipality; 0 otherwise.

Income (no answer): Equal to 1 for individuals who did not share their income, 0 otherwise.

Income: Reported monthly income coded into an ordinal variable with 14 values: 0 for "No income," 1 for "R1-R500," 2 for "R 501R750," 3 for "R 751-R1,000," 4 for "R1001-R1,500," 5 for "R1,501-R2,000," 6 for "R2,001-R3,000," 7 for "R3,001-R5,000," 8 for "R5,001-R7,500," 9 for "R7,501-R10,000," 10 for "R10,001-R15,000," 11 for "R15,001-R20,000," 12 for "R20,001-R30,000," and 13 for "R30,001+." Where respondents refused to answer or did not know, the response is coded as 0 , but we allow for a separate intercept with the "Income (no answer)" indicator. 
Locale: A set of indicator variables for whether respondents are residents of "Metropolitan" (the reference category), "Urban," or "Rural" locales.

Mayor approval: Responses to the SACS survey question "How well or badly do you feel that the Mayor of the municipality in which you live is doing his/her job?" Responses coded 0 for "Very badly," 1 for "Badly," 2 for "Well," and 3 for "Very well." "Don't know" is coded as missing, although results are robust to coding them as a middle category instead.

National government approval: Responses to the SACS survey question "How well or badly do you feel that the National Government is doing its job?" Responses coded 0 for "Very badly," 1 for "Badly," 2 for "Well," and 3 for "Very well." "Don't know" is coded as missing.

Mayor approval (very bad): Responses to the SACS survey question "How well or badly do you feel that the Mayor of the municipality in which you live is doing his/her job?", coded as a dichotomous indicator equal to 1 only for the response "Very badly," 0 otherwise. "Don't know" is coded as missing.

Worse: See above (by-elections dataset).

Better: See above (by-elections dataset).

Outcome change: See above (by-elections dataset).

Post-release (1-week window): Equal to 1 for dates in the one week following May 23, 2018, 0 otherwise.

Post-release (2-week window): Equal to 1 for dates in the two weeks following May 23, 2018, 0 otherwise.

Post-release (3-week window): Equal to 1 for dates in the three weeks following May 23, 2018, 0 otherwise.

Post-release (4-week window): Equal to 1 for dates in the four weeks following May 23, 2018, 0 otherwise.

Post-release: Equal to 1 for dates on or after May 23, 2018, the release date of the Auditor General's report in that year, 0 otherwise.

Race: A set of indicator variables based on reported race, including categories "Black" (reference category), "Coloured," "Indian," and "White." 
Unemployed: Equal to 1 for individuals whose response to the question on "Work status" was "Not working: unemployed," 0 otherwise. 
Table A21: Summary statistics (by-elections data)

\begin{tabular}{|c|c|c|c|c|c|}
\hline Variable & Obs & Mean & Std. Dev. & Min & Max \\
\hline ANC majority & 270 & 0.763 & 0.426 & 0 & 1 \\
\hline Attribution barriers & 270 & 0.233 & 0.424 & 0 & 1 \\
\hline Bad audit & 269 & 0.346 & 0.476 & 0 & 1 \\
\hline Better & 268 & 0.261 & 0.440 & 0 & 1 \\
\hline Chief & 270 & 0.633 & 0.483 & 0 & 1 \\
\hline Competitive council & 269 & 0.520 & 0.501 & 0 & 1 \\
\hline Days since last regular election & 270 & 1060.033 & 433.242 & 112 & 1785 \\
\hline Days since last release $(\log )$ & 211 & 4.797 & 0.926 & 0.000 & 5.943 \\
\hline Good audit & 269 & 0.409 & 0.493 & 0 & 1 \\
\hline Households with internet & 269 & 0.284 & 0.094 & 0.125 & 0.514 \\
\hline Households with radio & 269 & 0.652 & 0.077 & 0.346 & 0.787 \\
\hline Households with television & 269 & 0.670 & 0.144 & 0.277 & 0.873 \\
\hline Initial turnout & 270 & 0.541 & 0.101 & 0.004 & 0.743 \\
\hline Initial vote share & 270 & 0.673 & 0.224 & 0.028 & 1.000 \\
\hline Linguistic fractionalization & 269 & 2.076 & 1.478 & 1.013 & 6.887 \\
\hline Media office & 270 & 0.411 & 0.493 & 0 & 1 \\
\hline Outcome change & 268 & 0.131 & 0.613 & -1 & 1 \\
\hline Outcome in levels & 269 & 0.063 & 0.868 & -1 & 1 \\
\hline Rural & 269 & 0.383 & 0.487 & 0 & 1 \\
\hline Turnout & 270 & 0.390 & 0.124 & 0.030 & 0.713 \\
\hline Vote share & 270 & 0.655 & 0.235 & 0.012 & 0.980 \\
\hline Window 120 & 270 & 0.352 & 0.478 & 0 & 1 \\
\hline Window 30 & 270 & 0.030 & 0.170 & 0 & 1 \\
\hline Window 60 & 270 & 0.144 & 0.352 & 0 & 1 \\
\hline Window 90 & 270 & 0.200 & 0.401 & 0 & 1 \\
\hline Worse & 268 & 0.131 & 0.338 & 0 & 1 \\
\hline
\end{tabular}


Table A22: Summary statistics (survey data)

\begin{tabular}{|c|c|c|c|c|c|}
\hline Variable & Obs & Mean & Std. Dev. & Min & Max \\
\hline Age & 3,972 & 40.806 & 16.151 & 18 & 100 \\
\hline Better & 3,920 & 0.065 & 0.247 & 0 & 1 \\
\hline Corruption very important & 3,873 & 0.653 & 0.476 & 0 & 1 \\
\hline Date & 3,972 & 55.314 & 34.759 & 1 & 112 \\
\hline Date cubed & 3,972 & 363672.700 & 394929.200 & 1 & 1404928 \\
\hline Date squared & 3,972 & 4267.512 & 3802.219 & 1 & 12544 \\
\hline Education & 3,972 & 3.982 & 1.991 & 0 & 10 \\
\hline Female & 3,972 & 0.580 & 0.494 & 0 & 1 \\
\hline Heard of audits & 3,972 & 0.372 & 0.483 & 0 & 1 \\
\hline Income & 3,972 & 2.690 & 3.414 & 0 & 13 \\
\hline Income (no answer) & 3,972 & 0.386 & 0.487 & 0 & 1 \\
\hline Locale: Rural & 3,972 & 0.210 & 0.408 & 0 & 1 \\
\hline Locale: Urban & 3,972 & 0.256 & 0.436 & 0 & 1 \\
\hline Mayor approval & 3,447 & 1.299 & 0.965 & 0 & 3 \\
\hline Mayor approval (very bad) & 3,447 & 0.265 & 0.441 & 0 & 1 \\
\hline National government approval & 3,594 & 1.563 & 0.852 & 0 & 3 \\
\hline Outcome change & 3,920 & -0.193 & 0.535 & -1 & 1 \\
\hline Post-release & 3,972 & 0.259 & 0.438 & 0 & 1 \\
\hline Post-release (1-week window) & 3,972 & 0.010 & 0.097 & 0 & 1 \\
\hline Post-release (2-week window) & 3,972 & 0.102 & 0.303 & 0 & 1 \\
\hline Post-release (3-week window) & 3,972 & 0.231 & 0.421 & 0 & 1 \\
\hline Post-release (4-week window) & 3,972 & 0.256 & 0.436 & 0 & 1 \\
\hline Race: Coloured & 3,972 & 0.134 & 0.341 & 0 & 1 \\
\hline Race: Indian & 3,972 & 0.035 & 0.185 & 0 & 1 \\
\hline Race: White & 3,972 & 0.219 & 0.414 & 0 & 1 \\
\hline Unemployed & 3,972 & 0.402 & 0.490 & 0 & 1 \\
\hline Worse & 3,920 & 0.258 & 0.438 & 0 & 1 \\
\hline
\end{tabular}

Note: Sample restricted to respondents in municipalities without mayoral changes between the 2016 local

elections and the period covered by the survey in 2018 (excluding 26 such municipalities), as in Table 2. 